\title{
Modelling the global tropospheric ozone budget: exploring the variability in current models
}

\section{O. Wild}

Frontier Research Center for Global Change, JAMSTEC, Yokohama, Japan

now at: Centre for Atmospheric Science, University of Cambridge, UK

Received: 11 January 2007 - Published in Atmos. Chem. Phys. Discuss.: 8 February 2007

Revised: 4 May 2007 - Accepted: 4 May 2007 - Published: 21 May 2007

\begin{abstract}
What are the largest uncertainties in modelling ozone in the troposphere, and how do they affect the calculated ozone budget? Published chemistry-transport model studies of tropospheric ozone differ significantly in their conclusions regarding the importance of the key processes controlling the ozone budget: influx from the stratosphere, chemical processing and surface deposition. This study surveys ozone budgets from previous studies and demonstrates that about two thirds of the increase in ozone production seen between early assessments and more recent model intercomparisons can be accounted for by increased precursor emissions. Model studies using recent estimates of emissions compare better with ozonesonde measurements than studies using older data, and the tropospheric burden of ozone is closer to that derived here from measurement climatologies, $335 \pm 10 \mathrm{Tg}$. However, differences between individual model studies remain large and cannot be explained by surface precursor emissions alone; cross-tropopause transport, wet and dry deposition, humidity, and lightning also make large contributions. The importance of these processes is examined here using a chemistry-transport model to investigate the sensitivity of the calculated ozone budget to different assumptions about emissions, physical processes, meteorology and model resolution. The budget is particularly sensitive to the magnitude and location of lightning $\mathrm{NO}_{\mathrm{x}}$ emissions, which remain poorly constrained; the $3-8 \mathrm{TgN} / \mathrm{yr}$ range in recent model studies may account for a $10 \%$ difference in tropospheric ozone burden and a 1.4 year difference in $\mathrm{CH}_{4}$ lifetime. Differences in humidity and dry deposition account for some of the variability in ozone abundance and loss seen in previous studies, with smaller contributions from wet deposition and stratospheric influx. At coarse model resolutions stratospheric influx is systematically overestimated and dry deposition is underestimated; these differences are 5-8\%
\end{abstract}

Correspondence to: O. Wild

(oliver.wild@atm.ch.cam.ac.uk) at the $300-600 \mathrm{~km}$ grid-scales investigated here, similar in magnitude to the changes induced by interannual variability in meteorology. However, a large proportion of the variability between models remains unexplained, suggesting that differences in chemical mechanisms and dynamical schemes have a large impact on the calculated ozone budget, and these should be the target of future model intercomparisons.

\section{Introduction}

Ozone is an important greenhouse gas, a major component of photochemical smog, and the primary source of hydroxyl radicals which control the oxidizing capacity of the troposphere (e.g., Prather and Ehhalt, 2001). The abundance of $\mathrm{O}_{3}$ in the troposphere is controlled by transport from the $\mathrm{O}_{3}-$ rich stratosphere, by chemical production following the oxidation of hydrocarbons and $\mathrm{CO}$ in the presence of nitrogen oxides $\left(\mathrm{NO}_{\mathrm{x}}\right)$ and by removal via chemical destruction or dry deposition. The magnitudes of these sources and sinks have not been reliably quantified, and observational constraints on them remain poor. The chemical lifetime of $\mathrm{O}_{3}$ in the troposphere, typically days to weeks, is similar in magnitude to the dynamical timescales for transport and mixing, and thus the factors controlling $\mathrm{O}_{3}$ are not easily separable. The net effects of chemical processing are dependent on the balance between large production and destruction terms which dominate in different regions of the troposphere, and the importance of stratosphere-troposphere exchange (STE) is similarly dependent on the balance between downward transport of $\mathrm{O}_{3}$ from the stratosphere, mostly at mid-latitudes, and a smaller upward flux in tropical regions. The equilibrium between these chemical and dynamical fluxes constitutes a buffering of tropospheric $\mathrm{O}_{3}$, and poor estimates of one or more of these governing processes may be masked by readjustment of the others so that the abundance of $\mathrm{O}_{3}$ in the troposphere is not greatly affected. However, a quantitative

Published by Copernicus Publications on behalf of the European Geosciences Union. 
understanding of the processes controlling the production, redistribution and fate of $\mathrm{O}_{3}$ in the troposphere is required before a reliable assessment can be made of how $\mathrm{O}_{3}$ may respond to changes in anthropogenic emissions of trace gases or global climate.

Global chemistry-transport models (CTMs) that simulate the chemical and dynamical processes controlling $\mathrm{O}_{3}$ provide a self-consistent estimate of the key budget terms. Most CTMs can reproduce the seasonality and distribution of tropospheric $\mathrm{O}_{3}$ measured by ozonesondes in a climatological sense, but assessments of the relative importance of the controlling processes vary widely (Prather and Ehhalt, 2001). Recent model intercomparison studies estimate a net $\mathrm{O}_{3}$ influx of $550 \pm 170 \mathrm{Tg} / \mathrm{yr}$ from the stratosphere and a surface removal of $1000 \pm 200 \mathrm{Tg} / \mathrm{yr}$ by dry deposition, with net chemical production making up the balance of $450 \pm 300 \mathrm{Tg} / \mathrm{yr}$ (Stevenson et al., 2006). However, there are large differences between individual model studies in the importance of these terms reflecting differences in their treatments of chemical and dynamical processes. These differences highlight significant imperfections in our current understanding of the key factors involved (e.g., in the magnitude and distribution of emissions, chemical processing, and convection) and in their numerical representation at computationally-tractable temporal and spatial scales. CTMs are typically focussed on global-scale issues such as attribution of climate impacts due to changing patterns of fossil fuel combustion (Gauss et al., 2003; Dentener et al., 2006a), or assessment of the policy impacts of intercontinental transport of oxidants on air quality (e.g., Holloway et al., 2003). Many of the chemical and dynamical processes controlling $\mathrm{O}_{3}$ in the troposphere occur at much smaller temporal and spatial scales than can be resolved in these models, and thus important processes are parameterized, introducing additional uncertainty. Nevertheless, improved understanding of the interactions between tropospheric composition and climate, and in particular of how changes in climate may affect the sources and fate of tropospheric $\mathrm{O}_{3}$, requires that the principal terms in the $\mathrm{O}_{3}$ budget can be quantified in a reliable and consistent way so that the sensitivity of the budget to changes in transport, convection, chemistry and deposition can be evaluated reliably. Recent model intercomparison exercises have suggested that this may not currently be the case (Prather and Ehhalt, 2001; Stevenson et al., 2006).

The aims of this paper are to explore the differences seen in previous model estimates of the source and fate of tropospheric $\mathrm{O}_{3}$, and to investigate to what extent these arise from the use of different input conditions or from differences in model formulation. Differences in precursor emissions or meteorological data may mask the more subtle differences that reflect improved scientific understanding or deficiencies in process representation. Identifying the source of these differences is important for reducing the uncertainty in the modelled response of tropospheric $\mathrm{O}_{3}$ to applied changes and for interpreting the results of multi-model "ensemble" studies.
The sensitivity of the budget terms to key model processes is explored here in a consistent way with a single model. Section 2 reviews tropospheric $\mathrm{O}_{3}$ budgets from published studies and highlights the origins of some of the differences between them. Section 3 describes the limited observational constraints on the $\mathrm{O}_{3}$ budget. Section 4 then examines the sensitivity of the budget terms to emissions, meteorology, and key physical processes and interprets the variability seen in previous studies in light of these results. The implications of the results for future model intercomparison studies are outlined in Sect. 5.

\section{Tropospheric ozone budgets in global models}

A comparison of $\mathrm{O}_{3}$ budgets from published global model studies is presented in Table 1. The studies are ordered chronologically by publication date, and statistics from earlier studies summarised in the Intergovernmental Panel on Climate Change (IPCC) Third Assessment Report (TAR) (Prather and Ehhalt, 2001) are compared with those published since 2000 to show how the calculated $\mathrm{O}_{3}$ budget has evolved. There are large differences in the key terms between individual model studies: STE fluxes vary by a factor of four (340-1440 Tg/yr), deposition fluxes vary by almost a factor of three (530-1470 Tg/yr), and gross chemical production varies by a factor of two $(2330-5260 \mathrm{Tg} / \mathrm{yr})$. The tropospheric burden of $\mathrm{O}_{3}$ varies between 240 and $380 \mathrm{Tg}$. However, these studies vary widely in their precursor emissions and in model formulation and resolution. Many of the pioneering early studies used simplified chemistry schemes omitting oxidation of non-methane hydrocarbons (NMHC), and a number of them had unreasonably high estimates of stratospheric influx; compensation between the key terms in the budget leads several studies to conclude that the troposphere is a net chemical sink of $\mathrm{O}_{3}$. Recent studies have benefited from more detailed chemical schemes, improved understanding of the emissions of key precursor species, and better quality meteorological data at higher spatial resolution. This has reduced the variability in independent studies published since 2000 compared with those surveyed in the IPCC-TAR, but the $1 \sigma$ variability remains large: STE $530 \pm 100 \mathrm{Tg} / \mathrm{yr}$, net production $400 \pm 250 \mathrm{Tg} / \mathrm{yr}$, and deposition $950 \pm 220 \mathrm{Tg} / \mathrm{yr}$. It is not clear how much of this variability is due to the use of different input data (e.g., emissions or meteorological data) and how much is down to different model treatments of the key processes involved. These studies have typically used their own definitions of the tropopause and of the chemical fluxes constituting $\mathrm{O}_{3}$ production, making direct comparison of $\mathrm{O}_{3}$ burdens, lifetimes and tendencies particularly difficult.

A recent model intercomparison coordinated by the European Union project Atmospheric Composition Change: the European Network of Excellence (ACCENT) involved many of the models shown in Table 1 and aimed to reduce these 
Table 1. Global ozone budgets from published CTM studies ${ }^{\mathrm{a}}$.

\begin{tabular}{|c|c|c|c|c|c|c|c|c|c|c|c|c|}
\hline \multirow[b]{2}{*}{ Model } & \multirow[b]{2}{*}{ Resolution $^{\mathrm{b}}$} & \multicolumn{4}{|c|}{ Emissions } & \multicolumn{6}{|c|}{$\mathrm{O}_{3}$ Budget } & \multirow[b]{2}{*}{ Reference } \\
\hline & & $\mathrm{NO}_{\mathrm{x}}$ & $\mathrm{CO}$ & $\mathrm{HC}^{\mathrm{c}}$ & Isop & $\mathrm{P}$ & $\mathrm{L}$ & P-L & STE & Dep & Burd & \\
\hline MOGUNTIA & 10x10 L10 & 45 & 1550 & 0 & 0 & 3609 & 3183 & 427 & 528 & 953 & 253 & Lelieveld and van Dorland (1995) \\
\hline ECHAM3.2 & T21 L19 & 40 & 1400 & 0 & 0 & 3206 & 3037 & 170 & 575 & 740 & 236 & Roelofs and Lelieveld (1995) \\
\hline IMAGES & $5 \times 5$ L 25 & 33 & 1428 & $322 t$ & 220 & 4550 & 4000 & 550 & 550 & 1100 & - & Müller and Brasseur (1995) \\
\hline UIO & $8 \times 10$ L9 & 35 & 1575 & 150 & 180 & - & - & 295 & 846 & 1178 & 370 & Berntsen et al. (1996) \\
\hline GCTM & $265 \mathrm{~km} \mathrm{~L} 11$ & 40 & - & 0 & 0 & - & - & 128 & 696 & 825 & 298 & Levy et al. (1997) \\
\hline ECHAM4 & T30 L19 & 38 & 1900 & 0 & 0 & 3415 & 3340 & 75 & 459 & 534 & 271 & Roelofs and Lelieveld (1997) \\
\hline ECHAM/TM3 & $3.8 \times 5$ L9 & 38 & 1089 & 0 & 0 & 2894 & 3149 & -255 & 740 & 533 & 266 & Houweling et al. (1998) \\
\hline ECHAM/TM3 & $3.8 \times 5$ L9 & 38 & 1089 & 108 & 400 & 3979 & 4065 & -86 & 768 & 681 & 311 & Houweling et al. (1998) \\
\hline HGISS & $4 \times 5$ L9 & 42 & 1040 & 99 & 597 & 4100 & 3680 & 420 & 400 & 820 & 310 & Wang et al. (1998) \\
\hline MOZART & T42 L25 & 43 & 1219 & $251 t$ & 220 & 3018 & 2511 & 507 & 391 & 898 & - & Hauglustaine et al. (1998) \\
\hline CTMK & $4 \times 5$ L15 & 38 & - & 0 & 0 & 3694 & 3719 & -27 & 1429 & 1432 & - & Wauben et al. (1998) \\
\hline CTMK & $4 \times 5$ L15 & 38 & - & 0 & 0 & 3789 & 3536 & 252 & 1092 & 1363 & - & Wauben et al. (1998) \\
\hline MATCH & T21 L28 & 37 & 1350 & 0 & 0 & 2490 & 3300 & -810 & 1440 & 620 & - & Crutzen et al. (1999) \\
\hline MATCH-MPIC & T63 L28 & 39 & 1500 & 0 & 0 & 2334 & 2812 & -478 & 1103 & 621 & - & Lawrence et al. (1999) \\
\hline HGISS-GCM & $4 \times 5$ L9 & 40 & 1030 & 100 & 550 & 4330 & 3960 & 370 & 390 & 760 & 360 & Mickley et al. (1999) \\
\hline STOCHEM & $5 \times 5$ L9 & 41 & 1033 & 197 & 446 & 4323 & 3888 & 435 & 432 & 862 & 316 & Stevenson et al. (2000) \\
\hline UCI & $8 \times 10$ L9 & 44 & 1050 & 92 & 502 & 4229 & 3884 & 345 & 473 & 812 & 288 & Wild and Prather (2000) \\
\hline TM3 & $3.8 \times 5$ L9 & 46 & 1365 & 160 & 356 & 3314 & 3174 & 140 & 565 & 705 & 347 & Lelieveld and Dentener (2000) \\
\hline ECHAM4 & T30 L19 & 38 & 1750 & 0 & 0 & 3663 & 3699 & -36 & 607 & 570 & 271 & Roelofs and Lelieveld (2000) \\
\hline ECHAM4 & T30 L19 & 38 & 1148 & 118 & 400 & 4375 & 4302 & 73 & 590 & 668 & 294 & Roelofs and Lelieveld (2000) \\
\hline GEOS-CHEM & $4 \times 5$ L20 & 46 & 1043 & 103 & 397 & 4900 & 4300 & 600 & 470 & 1070 & 315 & Bey et al. (2001) \\
\hline GISS-GCM & $4 \times 5$ L9 & 38 & 1175 & 0 & 0 & - & - & 389 & 750 & 1140 & 262 & Shindell et al. (2001) \\
\hline CHASER & T21 L32 & 44 & 1227 & $145 t$ & 400 & 4895 & 4498 & 397 & 593 & 990 & 322 & Sudo et al. (2002) \\
\hline MOZART2 & T42 L34 & 44 & 1195 & $218 t$ & 410 & 5258 & 4749 & 509 & 343 & 857 & 362 & Horowitz et al. (2003) \\
\hline MATCH-MPIC & T21 L28 & 43 & 1261 & 175 & 350 & 4170 & 4090 & 80 & 630 & 700 & 306 & von Kuhlmann et al. (2003) \\
\hline MATCH-MPIC & T63 L28 & 43 & 1261 & 175 & 350 & 4560 & 4290 & 280 & 540 & 820 & 294 & von Kuhlmann et al. (2003) \\
\hline GISS-GCM & $4 \times 5$ L23 & 40 & 988 & 100 & 176 & - & - & 1049 & 417 & 1466 & 349 & Shindell et al. (2003) \\
\hline LMDz-INCA & $2.5 \times 3.8 \mathrm{~L} 19$ & 47 & 1364 & 0 & 0 & 4486 & 3918 & 567 & 523 & 1090 & 296 & Hauglustaine et al. (2004) \\
\hline UMD-CTM & $4 \times 5$ L20 & 41 & 1132 & 54 & 503 & - & - & - & 479 & 1290 & 340 & Park et al. (2004) \\
\hline IMPACT & 4x5 L52 & 38 & 1398 & $52 t$ & 502 & - & - & 161 & 663 & 826 & - & Rotman et al. (2004) \\
\hline STOCHEM & $5 \times 5$ L9 & 50 & 1114 & $179_{t}$ & 507 & 4975 & 4421 & 554 & 395 & 949 & 273 & Stevenson et al. (2004) \\
\hline FRSGC/UCI & T21 L19 & 42 & 1248 & 143 & 220 & 4091 & 3854 & 237 & 519 & 757 & 283 & Wild et al. (2004) \\
\hline SUNYA-GCCM & T42 L18 & 43 & 1167 & 170 & 220 & - & - & 513 & 606 & 1127 & 376 & Wong et al. (2004) \\
\hline $\begin{array}{l}\text { All Models } \\
(\text { mean } \pm \text { std.dev })\end{array}$ & 33 studies & $\begin{array}{l}41 \\
\pm 4\end{array}$ & $\begin{array}{r}1270 \\
\pm 222\end{array}$ & $\begin{array}{r}94 \\
\pm 89\end{array}$ & $\begin{array}{r}240 \\
\pm 210\end{array}$ & $\begin{array}{r}3948 \\
\pm 761\end{array}$ & $\begin{array}{r}3745 \\
\pm 554\end{array}$ & $\begin{array}{r}245 \\
\pm 346\end{array}$ & $\begin{array}{r}636 \\
\pm 273\end{array}$ & $\begin{array}{r}902 \\
\pm 255\end{array}$ & $\begin{array}{r}307 \\
\pm 38\end{array}$ & \\
\hline \multirow[t]{2}{*}{ IPCC-TAR $^{\mathrm{d}}$} & 12 studies & 39 & 1285 & 75 & 195 & 3448 & 3435 & 46 & 765 & 818 & 304 & Prather and Ehhalt (2001) \\
\hline & & \pm 3 & \pm 293 & \pm 89 & \pm 232 & \pm 730 & \pm 505 & \pm 403 & \pm 380 & \pm 265 & \pm 32 & \\
\hline \multirow[t]{2}{*}{ post-2000 } & 17 studies & 43 & 1186 & 122 & 338 & 4465 & 4114 & 396 & 529 & 949 & 314 & \\
\hline & & \pm 3 & \pm 122 & \pm 66 & \pm 162 & \pm 514 & \pm 409 & \pm 247 & \pm 105 & \pm 222 & \pm 33 & \\
\hline \multirow[t]{2}{*}{ ACCENT } & 21 models & 51 & 1078 & $125 t$ & 470 & 5110 & 4668 & 442 & 552 & 1003 & 344 & Stevenson et al. (2006) \\
\hline & & \pm 2 & \pm 57 & - & \pm 66 & \pm 606 & \pm 727 & \pm 309 & \pm 168 & \pm 200 & \pm 39 & \\
\hline
\end{tabular}

${ }^{a}$ Emissions and budgets are in $\mathrm{Tg} \mathrm{yr}^{-1}\left(\mathrm{TgN} \mathrm{yr}^{-1}\right.$ for $\mathrm{NO}_{\mathrm{x}}$ and $\mathrm{TgC} \mathrm{yr}^{-1}$ for hydrocarbons); dashes indicate budget data unavailable.

${ }^{\mathrm{b}}$ Resolution in degrees (latitude by longitude) and number of model levels; spectral truncations of T21, T30, T42 and T63 are used to label Gaussian grids with approximate resolutions of $5.6^{\circ}, 3.8^{\circ}, 2.8^{\circ}$ and $1.9^{\circ}$ respectively.

${ }^{\mathrm{c}}$ Non-methane hydrocarbons excluding isoprene and terpenes; $t$ label indicates terpenes also emitted (an additional $100-170 \mathrm{TgC}^{-1} \mathrm{yr}^{-1}$ ).

d Selected studies published before 2000 shown in Table 4.12 of the IPCC Third Assessment Report, with the entry for Wauben et al. (1998) corrected.

uncertainties by constraining fossil fuel precursor emissions and applying consistent tropopause diagnostics across all participating models (Dentener et al., 2006a; Stevenson et al., 2006). The budget terms calculated in this study were higher than those from previous studies, and the variability in the terms was also larger, despite the more tightly constrained conditions. In particular, there is an increase in gross production between the IPCC-TAR ( $3450 \mathrm{Tg} / \mathrm{yr})$, studies published since $2000(4470 \mathrm{Tg} / \mathrm{yr})$ and the ACCENT intercomparison $(5110 \mathrm{Tg} / \mathrm{yr})$, which is accompanied by a $10 \%$ increase in 

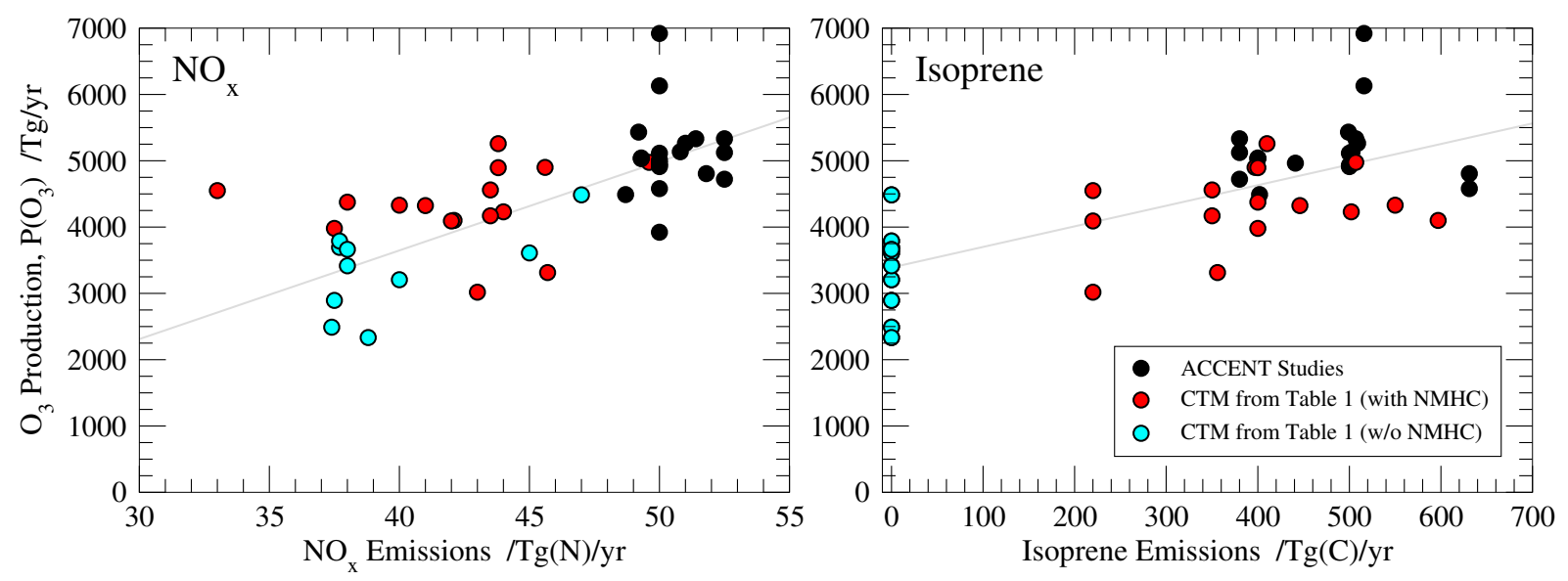

Fig. 1. Relationship between gross $\mathrm{O}_{3}$ production, $\mathrm{P}\left(\mathrm{O}_{3}\right)$, and precursor emissions for the model studies described in Table 1 with and without hydrocarbon oxidation and for the ACCENT model intercomparison studies described in Stevenson et al. (2006).

$\mathrm{O}_{3}$ burden, a $20 \%$ increase in deposition, and a drop in the tropospheric lifetime of $\mathrm{O}_{3}$ from 24 to 22 days. Higher estimates of precursor emissions make a substantial contribution to the increased production, as noted in regression analyses by Wu et al. (2007), and largely reflect improved understanding of $\mathrm{NO}_{\mathrm{x}}$ sources and emission factors. The sensitivity of gross $\mathrm{O}_{3}$ production to surface emissions of $\mathrm{NO}_{\mathrm{x}}$ and isoprene $\left(\mathrm{C}_{5} \mathrm{H}_{8}\right)$ is shown in Fig. 1 for published studies and for individual models contributing to the ACCENT intercomparison. While the strong dependence on emissions is clear, there is a large scatter in these plots, even for the relatively well-constrained ACCENT studies. The variation in emissions for the ACCENT models reflects differences in natural sources of $\mathrm{NO}_{\mathrm{x}}$ and isoprene which are interactive with model vegetation and meteorology in many of the models. The scatter indicates that other factors have an important influence on the budget. A major goal of the present study is to investigate the effects of these processes more closely using the tighter constraints imposed by application of a single model framework, and ensuring that comparison of budget terms is fully self-consistent.

\section{Constraints from observations}

Of the budget terms considered here only influx of $\mathrm{O}_{3}$ from the stratosphere has been adequately estimated from observational data. Murphy and Fahey (1994) used observed midlatitude $\mathrm{N}_{2} \mathrm{O}-\mathrm{O}_{3}$ correlations and an upward flux of $\mathrm{N}_{2} \mathrm{O}$ derived from a budget analysis to derive a net downward flux of $\mathrm{O}_{3}$ of $450 \mathrm{Tg} / \mathrm{yr}$, with a range of $200-870 \mathrm{Tg} / \mathrm{yr}$. Gettelman et al. (1997) used lower stratospheric $\mathrm{O}_{3}$ measurements and calculations of the residual circulation to derive a net downward flux of $510 \mathrm{Tg} / \mathrm{yr}$ at $100 \mathrm{hPa}$ (with a range of 450$590 \mathrm{Tg} / \mathrm{yr}$ ). McLinden et al. (2000) reduced the uncertainty in the analysis of Murphy and Fahey (1994) by considering the tighter $\mathrm{N}_{2} \mathrm{O}-\mathrm{NO}_{\mathrm{y}}$ and $\mathrm{NO}_{\mathrm{y}}-\mathrm{O}_{3}$ relationships separately, estimating a flux of $475 \pm 120 \mathrm{Tg} / \mathrm{yr}$, and further refinements by Olsen et al. (2001) led to the best estimate currently available, $550 \pm 140 \mathrm{Tg} / \mathrm{yr}$. Most model studies published since 2000 fall within this range, and the mean influx from the ACCENT model intercomparison was $552 \mathrm{Tg} / \mathrm{yr}$. However, this agreement masks significant differences in the magnitude and location of cross-tropopause fluxes and in treatment of stratospheric $\mathrm{O}_{3}$, and does not constitute an independent comparison as some models apply a flux constraint through use of tuned upper boundary conditions or an artificial stratospheric $\mathrm{O}_{3}$ tracer such as Synoz (McLinden et al., 2000).

In the absence of reliable observation-based estimates of global deposition fluxes or chemical production, the best remaining constraint is on the abundance of $\mathrm{O}_{3}$ itself. Without details of the seasonal, geographical and altitudinal variations in $\mathrm{O}_{3}$ from previous studies only a simple comparison of the mean annual global tropospheric burden is possible here. However, the tropospheric $\mathrm{O}_{3}$ burden and its dependence on the definition of the tropopause has not been evaluated previously. The tropospheric burden is estimated here from three different climatologies built from available ozonesonde, satellite and surface measurements, and using a number of different dynamical and thermal definitions of the tropopause, see Table 2 . The climatologies were interpolated onto a common $4^{\circ} \times 5^{\circ}$ grid and integrated from the surface to a tracer tropopause defined by a given abundance of $\mathrm{O}_{3}(100,120$ or $150 \mathrm{ppb})$, a thermal tropopause based on a lapse rate of $2 \mathrm{~K} \mathrm{~km}^{-1}$ following the WMO definition, or a dynamical tropopause based on potential vorticity (PV) using the lower of the $P V=2.0$ surface and the tropical $380 \mathrm{~K}$ isentrope. For comparison, a cold-point tropopause based on the tropical temperature minimum is shown (a WMO thermal tropopause was applied in the extra-tropics), and a stepped- 
Table 2. Estimated annual mean tropospheric $\mathrm{O}_{3}$ burdens (in $\mathrm{Tg}$ ) based on $\mathrm{O}_{3}$ climatologies and FRSGC/UCI CTM fields with different definitions of the tropopause.

\begin{tabular}{|c|c|c|c|c|c|c|c|}
\hline \multirow[b]{2}{*}{$\mathrm{O}_{3}$ Fields } & \multicolumn{3}{|c|}{$\mathrm{O}_{3}$ Tracer Tropopause } & \multirow{2}{*}{$\begin{array}{c}\text { Pressure } \\
100 / 250 \mathrm{hPa}\end{array}$} & \multicolumn{2}{|c|}{ Thermal Tropopause } & \multirow{2}{*}{$\begin{array}{l}\text { Pot. Vorticity } \\
2.0 \mathrm{PVU}\end{array}$} \\
\hline & $100 \mathrm{ppb}$ & $120 \mathrm{ppb}$ & $150 \mathrm{ppb}$ & & WMO & Cold Point & \\
\hline \multicolumn{8}{|l|}{$\mathrm{O}_{3}$ Climatology } \\
\hline Li and Shine (1995) & 295 & 318 & 344 & 382 & 383 & 408 & 362 \\
\hline Fortuin and Kelder (1998) & 295 & 312 & 333 & 345 & 347 & 370 & 332 \\
\hline Logan (1999) & 292 & 307 & 327 & 322 & 325 & 343 & 308 \\
\hline \multicolumn{8}{|l|}{$C T M \mathrm{O}_{3}$ fields } \\
\hline BASE emissions & 260 & 273 & 290 & 266 & 296 & 321 & 285 \\
\hline IIASA emissions & 285 & 300 & 318 & 295 & 327 & 353 & 316 \\
\hline ACCENT run & 303 & 316 & 331 & 313 & 338 & 363 & 323 \\
\hline
\end{tabular}

isobaric tropopause typical of crude model diagnostics is also used $\left(100 \mathrm{hPa}\right.$ in the tropics and $250 \mathrm{hPa}$ poleward of $30^{\circ}$ ). Thermal and dynamical tropopauses were calculated using monthly-mean data for year 2000 from the European Centre for Medium-Range Weather Forecasts (ECMWF); burdens calculated with 1997 data differ by less than $2 \mathrm{Tg}(<1 \%)$. These comparisons provide only crude estimates of the true tropospheric burden, neglecting temporal or spatial variations in tropopause height which may bias it high or low, but they provide a convenient benchmark against which model simulations can be compared.

Use of a tracer tropopause provides the greatest consistency in $\mathrm{O}_{3}$ burden for the different climatologies, as differences in $\mathrm{O}_{3}$ distribution are suppressed. This definition is the simplest to employ when comparing model studies, and based on the $150 \mathrm{ppb}$ level recommended by Prather and Ehhalt (2001) suggests a tropospheric burden of $335 \pm 10 \mathrm{Tg}$ for the three climatologies used here. Thermal definitions generally give higher burdens, as noted by Bethan et al. (1996), and are more sensitive to $\mathrm{O}_{3}$ differences in the tropopause region and thus more variable; the WMO lapserate definition gives a burden of about $352 \pm 30 \mathrm{Tg}$. Interestingly, the crude pressure tropopause gives very similar burdens to the WMO lapse-rate tropopause for all three climatologies used here, but note that they are quite different for typical model fields (discussed below), highlighting systematic differences in $\mathrm{O}_{3}$ distribution between modelled and climatological fields. The $\mathrm{PV}=2.0$ dynamical tropopause gives similar burdens to the $150 \mathrm{ppb}$ tracer tropopause for both model and climatological fields, and burdens are consistently lower than with the WMO lapse-rate definition.

There is considerable uncertainty in these estimates due to the sparse coverage of ozonesonde sites, but the $\mathrm{O}_{3}$ burdens derived here are generally lower than the $370 \mathrm{Tg}$ burden recommended by Prather and Ehhalt (2001). The dynamical tropopause is represented well by the $150 \mathrm{ppb} \mathrm{O}_{3}$ tracer tropopause, and the mean burden of $344 \mathrm{Tg}$ from the
ACCENT model intercomparison (reduced to $336 \mathrm{Tg}$ after removing model outliers) (Stevenson et al., 2006) which used this tracer tropopause is in good agreement with the $335 \pm 10 \mathrm{Tg}$ range estimated here from measurement climatology. The variability in burden for a single $\mathrm{O}_{3}$ distribution based on different definitions of the tropopause is as much as $\pm 15 \%$, suggesting that differences in definition make an important contribution to the differences between model burdens shown in Table 1.

\section{CTM sensitivity studies}

The dependence of the calculated $\mathrm{O}_{3}$ budget on precursor emissions and on physical and meteorological variables is investigated here with a global CTM. Altering variables independently allows an assessment of their contributions to the model differences seen in Table 1, and use of a single model framework ensures that the comparison of their relative importance is self-consistent. A similar approach has been adopted in a recent study of uncertainties in a regional model (Mallet and Sportisse, 2006). Previous global studies have focussed on the effects of individual variables, e.g., hydrocarbon oxidation (Houweling et al., 1998; Roelofs and Lelieveld, 2000; von Kuhlmann et al., 2004), STE (Wauben et al., 1998), model resolution (von Kuhlmann et al., 2003; Wild and Prather, 2006), lightning $\mathrm{NO}_{\mathrm{x}}$ emissions (Labrador et al., 2005), convection (Lawrence et al., 2003; Doherty et al., 2005), and interannual variability in meteorology (Zeng and Pyle, 2005), but have not compared their effects in a comprehensive or systematic way.

The model used here is the Frontier Research System for Global Change (FRSGC) version of the University of California, Irvine (UCI) CTM described in Wild and Prather (2000) with the configuration used in Wild et al. (2004). Pieced-forecast meteorological data generated by the European Centre for Medium-Range Weather Forecasts Integrated Forecast System (ECMWF-IFS) are used to drive 


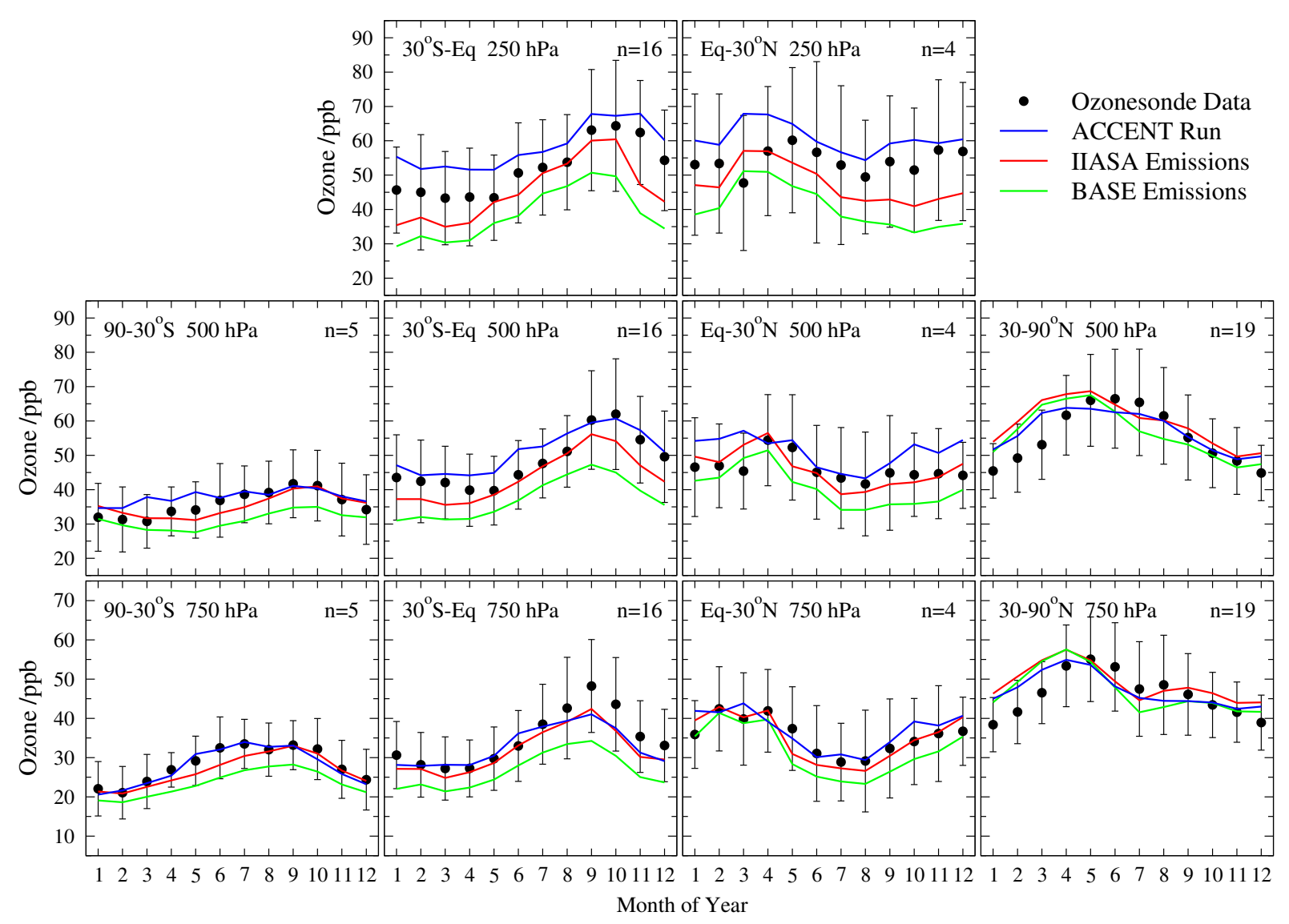

Fig. 2. Comparison of the annual cycle of $\mathrm{O}_{3}$ in the FRSGC/UCI CTM with ozonesonde measurements at 750,500 and $250 \mathrm{hPa}$ averaged over four latitude bands. Results for 3 model simulations are shown: the BASE run (green), a run with IIASA emissions (red) and a T42L37 run for year 2000 with IIASA emissions (blue). Monthly mean mixing ratios at each site are averaged over each band and are compared with model fields sampled in the same way; error bars show the average interannual standard deviation at each station. Ozonesonde data are from Logan (1999) and Thompson et al. (2003); the number of stations in each band is given by " $n$ ".

the model. The model includes an explicit treatment of $\mathrm{HO}_{\mathrm{x}} / \mathrm{O}_{\mathrm{x}} / \mathrm{NO}_{\mathrm{x}}$ chemistry and $\mathrm{CH}_{4}$ oxidation, and a lumped NMHC chemistry for the representative species butane, propene, xylene and isoprene. The 70-80 runs performed here use the same initial conditions and 8-month spin-up period, but a different variable is altered in each case to quantify its effect on the $\mathrm{O}_{3}$ budget. The tropopause is diagnosed on-line using the $120 \mathrm{ppb}$ abundance of Linoz, an $\mathrm{O}_{3}$-like tracer with a linearised $\mathrm{O}_{3}$ chemistry in the stratosphere, no loss in the free troposphere and a 2-day relaxation to $20 \mathrm{ppb}$ at the surface (McLinden et al., 2000). For consistency with other published studies, $\mathrm{O}_{3}$ budget terms are diagnosed from monthly-mean model output based on a $150 \mathrm{ppb}$ $\mathrm{O}_{3}$ tracer tropopause (Prather and Ehhalt, 2001; Stevenson et al., 2006). The difference in $\mathrm{O}_{3}$ burden between this diagnostic $\mathrm{O}_{3}$ tropopause and the on-line Linoz tropopause is generally less than $10 \mathrm{Tg}$, about $3 \%$. The STE flux is inferred as the residual term in the $\mathrm{O}_{3}$ budget after accounting for the diagnosed net chemical production and deposition and the net change in burden over the year. Gross chemical pro- duction and destruction of $\mathrm{O}_{3}$ are diagnosed from the model chemistry scheme; gross destruction is based on the reaction fluxes of $\mathrm{O}\left({ }^{1} \mathrm{D}\right)$ with water vapour and of $\mathrm{O}_{3}$ with $\mathrm{HO}_{\mathrm{x}}$ and alkenes, and gross production is taken as the difference between the calculated chemical $\mathrm{O}_{3}$ tendency and the diagnosed destruction rate to ensure mass consistency.

Two sets of emissions scenarios are used in these experiments. The base scenario ("BASE") for $\mathrm{NO}_{\mathrm{x}}, \mathrm{CO}$ and NMHC loosely represents 1990's understanding, and is taken from version 2 of the EDGAR database for 1990 (Olivier et al., 1996) with isoprene emissions from Guenther et al. (1995) reduced to $220 \mathrm{TgC} / \mathrm{yr}$ following Hauglustaine et al. (1998). A second, updated scenario ("IIASA") uses industrial emissions distributions from EDGAR v3.2 for 1995 (Olivier and Berdowski, 2001) scaled to the year 2000 using emission data from the International Institute for Applied Systems Analysis (IIASA) (Dentener et al., 2005), as recommended for the recent ACCENT model intercomparison. Biomass burning emissions from van de Werf et al. (2003) are used with this scenario, together with the full $500 \mathrm{TgC} / \mathrm{yr}$ 
of isoprene emissions from Guenther et al. (1995). Lightning $\mathrm{NO}_{\mathrm{x}}$ emissions of $5 \mathrm{TgN} / \mathrm{yr}$ and $\mathrm{CH}_{4}$ emissions of $550 \mathrm{Tg} / \mathrm{yr}$ are used with both these scenarios. The sensitivity studies described here use the BASE emissions unless otherwise indicated, and are run with 1996 meteorology at T21L19 resolution $\left(5.6^{\circ} \times 5.6^{\circ}\right.$ resolution with 19 levels $)$.

Model runs are evaluated by comparing with ozonesonde observations from the period 1980-1993 (Logan, 1999), supplemented by additional data from the tropics between 1997 and 2002 (Thompson et al., 2003). Monthly interannual mean $\mathrm{O}_{3}$ mixing ratios at selected altitudes at each location are averaged over four latitude bands and compared with monthly means from model simulations sampled at the same locations, following the method of Stevenson et al. (2006), see Fig. 2. Three model scenarios are shown to illustrate the range of $\mathrm{O}_{3}$ responses: the control run (BASE), a run with updated emissions (IIASA), and a run contributed to the ACCENT intercomparison (ACCENT) which used IIASA emissions in different model conditions (year 2000 meteorology with higher horizontal and vertical resolution, T42L37, and minor improvements to model physics described in Wild and Prather, 2006). While the magnitude and seasonality of $\mathrm{O}_{3}$ are captured reasonably well in these runs, a number of discrepancies clearly remain, most notably in the wintertime at Northern mid-latitudes and in the tropical upper troposphere. The difference between BASE and IIASA runs shows how changes in precursor emissions alone contribute to changes in $\mathrm{O}_{3}$; comparison with observations suggests that emissions in the BASE scenario are too low, particularly in the tropics. Differences between the IIASA and ACCENT runs reflect changes in meteorology and resolution, although differences in the tropical upper troposphere are influenced by the use of marginally higher lightning $\mathrm{NO}_{\mathrm{x}}$ emissions in the ACCENT run $(6.5 \mathrm{TgN} / \mathrm{yr}$ rather than $5 \mathrm{TgN} / \mathrm{yr})$ and application of the observation-based emissions profiles of Pickering et al. (1998) in place of uniform profiles based on Price and Rind (1992).

To provide a more quantitative measure of model performance, the mean bias and root mean square (RMS) error are calculated over the ten locations shown in Figure 2 weighted by pressure so that they are representative of the $\mathrm{O}_{3}$ burden. The annual mean bias over these locations for the BASE, IIASA and ACCENT runs is $-5.3,-1.0$ and $1.6 \mathrm{ppb}$, respectively, and the RMS errors are 7.8, 4.6 and $4.3 \mathrm{ppb}$. Comparison of the annual mean tropospheric $\mathrm{O}_{3}$ burden with climatologies provides an additional measure of model performance, see Table 2. Using the BASE emissions the $\mathrm{O}_{3}$ burden is consistently low for all tropopause definitions; the comparison is best for the ACCENT run where there is close agreement with the Fortuin and Kelder (1998) climatology. The largest differences are seen for the simple diagnostic tropopause based on pressure, reflecting differences in the geographical distribution of $\mathrm{O}_{3}$ in the tropopause region and the lack of longitudinal variation in the climatologies.

\subsection{Sensitivity to precursor emissions}

The dependence of $\mathrm{O}_{3}$ production on precursor emissions shown in Fig. 1 suggests that increases in $\mathrm{NO}_{\mathrm{x}}$ and isoprene emissions between the IPCC-TAR survey and the ACCENT studies make a large contribution to the differences seen in the calculated $\mathrm{O}_{3}$ budget. To examine this, surface emissions of $\mathrm{NO}_{\mathrm{x}}$ and isoprene are increased independently by replacing the BASE emissions with the higher values recommended for the ACCENT runs, see Table 3. The increase from 42 to $51 \mathrm{TgN} / \mathrm{yr}$ for $\mathrm{NO}_{\mathrm{x}}$ and from 220 to $500 \mathrm{TgC} / \mathrm{yr}$ for isoprene each contribute an additional $450 \mathrm{Tg}$ of gross $\mathrm{O}_{3}$ production per year. Scaled to the mean emission increases between the IPCC-TAR survey and the ACCENT studies, these changes account for about $1100 \mathrm{Tg} / \mathrm{yr}$ of additional production, $66 \%$ of the $1660 \mathrm{Tg} / \mathrm{yr}$ increase in mean production between the studies. Production is enhanced more with increased isoprene than with increased $\mathrm{NO}_{\mathrm{x}}$, but a greater proportion of this occurs in the boundary layer where surface deposition is greater, and thus the increase in the tropospheric burden is less. Higher $\mathrm{NO}_{\mathrm{x}}$ and isoprene emissions both lead to more $\mathrm{O}_{3}$ in the lower troposphere and thus to a decrease in its tropospheric lifetime, but they have opposing effects on the lifetime of $\mathrm{CH}_{4}$, as $\mathrm{NO}_{\mathrm{x}}$ is a net source of $\mathrm{OH}$ while isoprene is a net sink. The greatly reduced mean bias and RMS error compared with ozonesonde data suggest that the higher $\mathrm{NO}_{\mathrm{x}}$ and isoprene emissions recommended for the ACCENT runs are more appropriate for present-day studies than those in the BASE scenario.

These emission scenarios are compared with those used in the OxComp model intercomparison conducted for the IPCC-TAR (Prather and Ehhalt, 2001), and with the IIASA emissions. The budget terms with the OxComp emissions are very similar to those in the increased- $\mathrm{NO}_{\mathrm{x}}$ run, $\mathrm{BASE}+\mathrm{N}$, and the IIASA emissions give budgets similar to the increased- $\mathrm{NO}_{\mathrm{x}}$ and isoprene run, BASE+NI. Although the differences in the $\mathrm{O}_{3}$ lifetime between these runs and the equivalent BASE runs are small, the $\mathrm{CH}_{4}$ lifetime changes significantly as emissions of $\mathrm{CO}$ and NMHC differ in the OxComp and IIASA scenarios.

To explore the full sensitivity of the $\mathrm{O}_{3}$ budget to emissions of $\mathrm{NO}_{\mathrm{x}}$ and isoprene, a series of 20 runs have been performed using isoprene emissions of $0,220,350,500$ and $650 \mathrm{TgC} / \mathrm{yr}$ and $\mathrm{NO}_{\mathrm{x}}$ emissions of $30,42,51$ and $60 \mathrm{TgN} / \mathrm{yr}$. Isoprene emissions were scaled linearly on the distribution of Guenther et al. (1995), while $\mathrm{NO}_{\mathrm{x}}$ emissions were varied non-linearly, with the $30 \mathrm{TgN} / \mathrm{yr}$ scenario representing 1970 conditions and the $60 \mathrm{TgN} / \mathrm{yr}$ scenario scaled to IIASA current-legislation emissions for 2030 (Dentener et al., 2005). The variation in key budget terms is shown in Fig. 3. The gross production and burden of $\mathrm{O}_{3}$ both increase steadily with increasing precursor emissions, consistent with the changes seen in the published budgets (see Fig. 1 and Table 1) and the $\mathrm{O}_{3}$ lifetime is reduced as chemical destruction and deposition increase. The contrasting effects of $\mathrm{NO}_{\mathrm{x}}$ and 
Table 3. Annual ozone budgets in the FRSGC/UCI CTM: sensitivity to precursor emissions ${ }^{\mathrm{a}}$.

\begin{tabular}{|c|c|c|c|c|c|c|c|c|c|c|c|c|c|c|c|}
\hline \multirow[b]{2}{*}{ Run } & \multirow[b]{2}{*}{ Emissions Scenario } & \multicolumn{4}{|c|}{ Emissions } & \multicolumn{6}{|c|}{$\mathrm{O}_{3}$ Budget } & \multicolumn{2}{|c|}{ Lifetimes } & \multicolumn{2}{|c|}{$\mathrm{O}_{3}$ Bias } \\
\hline & & $\mathrm{NO}_{\mathrm{x}}$ & Isop & $\mathrm{HC}$ & $\mathrm{CO}$ & $\mathrm{P}$ & $\mathrm{L}$ & $\mathrm{P}-\mathrm{L}$ & STE & Dep & Burd & $\mathrm{O}_{3}$ & $\mathrm{CH}_{4}$ & Mean & RMS \\
\hline \multicolumn{16}{|c|}{ Sensitivity to Isoprene and $N O_{\mathrm{x}}$ Emissions } \\
\hline Base & EDGAR v.2 & 42 & 220 & 143 & 1248 & 4078 & 3842 & 236 & 519 & 756 & 290 & 23.0 & 9.07 & -5.3 & 7.8 \\
\hline Base+I & Increased isoprene & 42 & 500 & 143 & 1248 & 4529 & 4224 & 305 & 513 & 817 & 303 & 21.9 & 9.59 & -3.2 & 6.3 \\
\hline Base $+\mathrm{N}$ & Increased $\mathrm{NO}_{\mathrm{x}}$ & 51 & 220 & 143 & 1248 & 4512 & 4227 & 286 & 516 & 803 & 306 & 22.2 & 8.17 & -2.8 & 6.1 \\
\hline Base+NI & $\mathrm{NO}_{\mathrm{x}}$ and isoprene & 51 & 500 & 143 & 1248 & 5022 & 4654 & 368 & 510 & 876 & 322 & 21.2 & 8.56 & -0.4 & 5.1 \\
\hline OxComp & OxComp emis & 50 & 220 & 161 & 1550 & 4454 & 4166 & 288 & 515 & 802 & 304 & 22.3 & 8.90 & -3.1 & 7.0 \\
\hline IIASA & IIASA 2000 emis & 51 & 500 & 122 & 1078 & 4926 & 4578 & 348 & 510 & 857 & 318 & 21.4 & 8.37 & -1.0 & 4.6 \\
\hline \multicolumn{16}{|c|}{ Sensitivity to Hydrocarbon Emissions } \\
\hline Base & EDGAR v.2 & 42 & 220 & 143 & 1248 & 4078 & 3842 & 236 & 519 & 756 & 290 & 23.0 & 9.07 & -5.3 & 7.8 \\
\hline FixCH4 & $\mathrm{CH}_{4}$ at $1760 \mathrm{ppb}$ & 42 & 220 & 143 & 1248 & 4117 & 3877 & 241 & 518 & 760 & 292 & 23.0 & 9.49 & -5.0 & 7.5 \\
\hline NoIsop & NMHC: no Isoprene & 42 & 0 & 143 & 1248 & 3616 & 3469 & 146 & 525 & 675 & 274 & 24.1 & 8.75 & -7.6 & 10.0 \\
\hline NoHVOC & NMHC: $\mathrm{C}_{2} \mathrm{H}_{6}$ only & 42 & 0 & 14 & 1248 & 3233 & 3183 & 50 & 528 & 584 & 258 & 25.0 & 8.57 & -10.0 & 11.7 \\
\hline NoVOC & NMHC: none & 42 & 0 & 0 & 1248 & 3171 & 3138 & 33 & 529 & 568 & 255 & 25.1 & 8.52 & -10.5 & 12.1 \\
\hline
\end{tabular}

a Emissions/budgets in $\mathrm{Tg} \mathrm{yr}^{-1}\left(\mathrm{TgN} \mathrm{yr}^{-1}\right.$ for $\mathrm{NO}_{\mathrm{x}}, \mathrm{TgC} \mathrm{yr}^{-1}$ for isoprene and $\left.\mathrm{NMHC}\right)$; $\mathrm{O}_{3}$ lifetime to chemical loss and deposition in days; $\mathrm{CH}_{4}$ lifetime to removal by tropospheric $\mathrm{OH}$ in years; biases in $\mathrm{ppb}$.

isoprene on $\mathrm{OH}$ lead to a balance such that the $\mathrm{CH}_{4}$ lifetime remains little affected by the combined emissions changes between the BASE and IIASA scenarios. However, the gradient of the slope is steep, and small changes in either $\mathrm{NO}_{\mathrm{x}}$ or isoprene separately can affect the lifetime substantially.

Note that the effects seen here are dependent on the complexity of the chemical scheme used in the model. The simplified scheme used here does not include isoprene nitrates, and more detailed studies treating their formation and deposition have found this to be a significant channel for removal of both isoprene intermediates and $\mathrm{NO}_{\mathrm{x}}$ (Pöschl et al., 2000; von Kuhlmann et al., 2004). It is not clear how many previous studies have included this pathway, but it has been shown to lead to stabilization of $\mathrm{O}_{3}$ production with increasing isoprene emissions (Wu et al., 2007). The differing complexity of chemical schemes may be an important source of differences between model studies and merits a more detailed investigation.

Table 3 also shows the sensitivity of the budget terms to the treatment of hydrocarbon emissions. Use of a globallyuniform field of $\mathrm{CH}_{4}$ instead of a transported $\mathrm{CH}_{4}$ tracer avoids the long spin-up times associated with $\mathrm{CH}_{4}$, but is shown to have very little effect on the $\mathrm{O}_{3}$ budget or lifetime. The $\mathrm{CH}_{4}$ lifetime is extended by about $5 \%$, reflecting a higher atmospheric burden in the stratosphere when using a globally-uniform field. Complete removal of all hydrocarbon emissions leads to a reduction in $\mathrm{O}_{3}$ production of about $900 \mathrm{Tg} / \mathrm{yr}$, half of which is due to isoprene, and a reduction in $\mathrm{O}_{3}$ burden of about $35 \mathrm{Tg}$ (12\%) compared with the BASE scenario. These results are consistent with those of Houweling et al. (1998) shown in Table 1.

\subsection{Sensitivity to physical processes}

Meteorological and dynamical processes influence the production, mixing and removal of $\mathrm{O}_{3}$ both directly and indirectly. Humidity, temperature and UV flux govern chemical reaction rates, boundary layer turbulence and convection redistribute $\mathrm{O}_{3}$ and its precursors, influencing $\mathrm{O}_{3}$ production and removal, and deposition processes remove $\mathrm{O}_{3}$ and soluble precursors. Ozone chemistry in the upper troposphere is influenced by the magnitude and distribution of lightningproduced $\mathrm{NO}_{\mathrm{x}}$ emissions and by direct influx of $\mathrm{O}_{3}$ from the stratosphere. Perturbation experiments are performed with the FRSGC/UCI CTM to explore the effect of these processes on $\mathrm{O}_{3}$, and the impacts on the key budget terms are shown in Table 4. For compatibility with the emissions studies in Sect. 4.1, the same BASE control run was used.

The stratospheric influx of $\mathrm{O}_{3}$ was increased by applying a consistent scaling of stratospheric Linoz chemistry. This leads to increased chemical removal and deposition in the troposphere, but also to decreased $\mathrm{O}_{3}$ production, as noted by Wauben et al. (1998), due to faster removal of $\mathrm{NO}_{\mathrm{x}}$. Of the additional $\mathrm{O}_{3}$ transported from the stratosphere, about $60 \%$ is destroyed chemically, $10 \%$ is deposited at the surface, and $30 \%$ displaces $\mathrm{O}_{3}$ that would have been formed in the troposphere, and is thus accounted for by decreased production. Quantifying the impact of STE on the tropospheric burden and lifetime of $\mathrm{O}_{3}$ is complicated by the choice of tropopause, however. Applying a thermal or dynamical tropopause or using the same location as in the control run leads to a large increase in the burden and an increase in lifetime associated with additional $\mathrm{O}_{3}$ at high altitude. Applying an $\mathrm{O}_{3}$ tracer tropopause, as here, leads to a much smaller increment in the burden as the tropospheric domain 

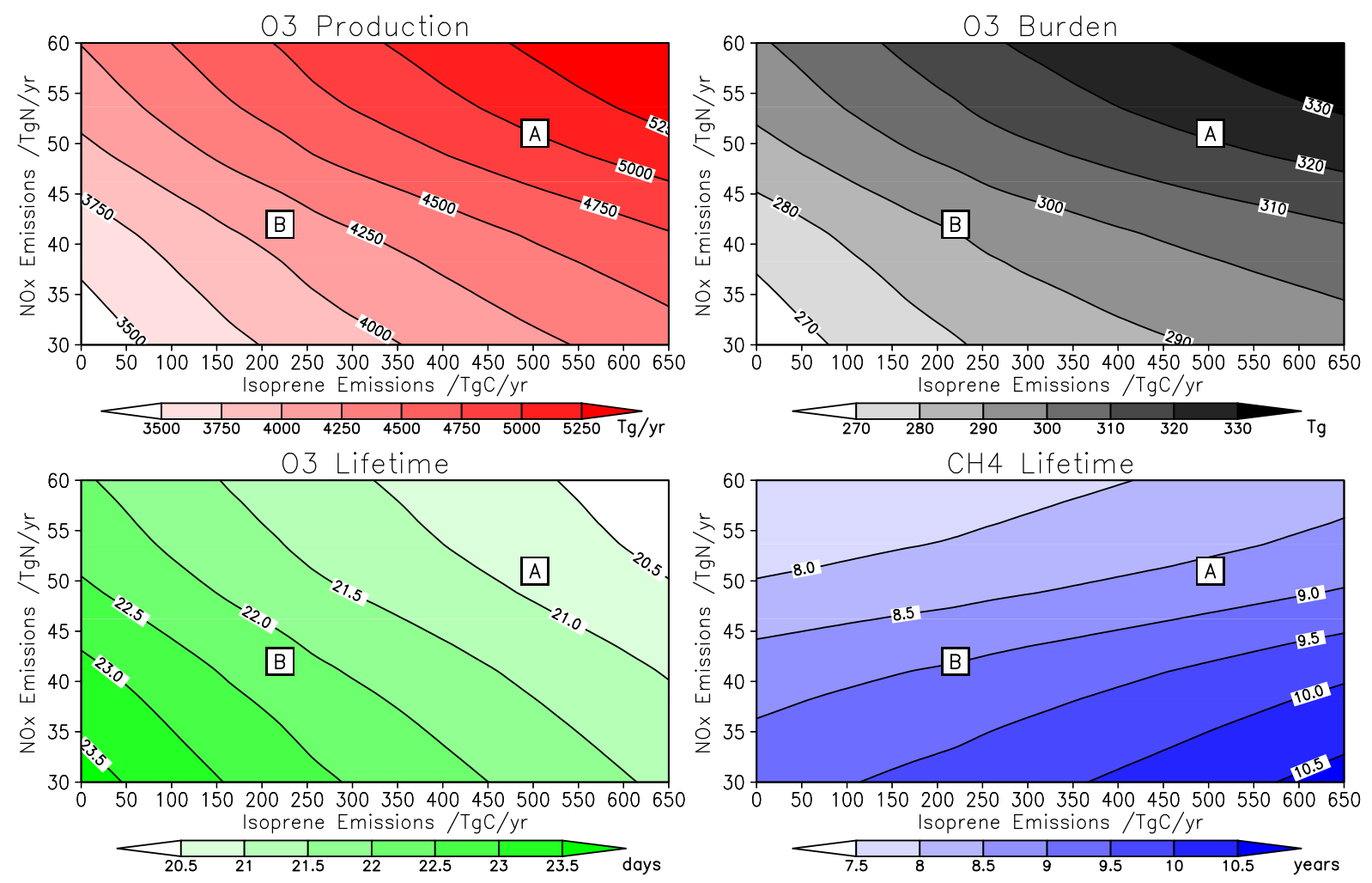

Fig. 3. Isopleth plots showing the variations in $\mathrm{O}_{3}$ production, $\mathrm{O}_{3}$ burden and the tropospheric lifetimes of $\mathrm{O}_{3}$ and $\mathrm{CH}_{4}$ for different combinations of $\mathrm{NO}_{\mathrm{x}}$ and Isoprene emissions using the FRSGC/UCI CTM with 1996 meteorology at T21 resolution. The BASE run ("B") and IIASA run for the ACCENT studies ("A") are indicated.

shrinks, and the $\mathrm{O}_{3}$ lifetime shows a marginal decrease, see Table 4. Use of a tracer tropopause clearly damps the calculated budget response to changes in STE. As removal of $\mathrm{O}_{3}$ by dry deposition changes only slowly along with the burden, the net impact of chemistry, P-L, is very sensitive to the STE flux used.

Dry deposition affects the $\mathrm{O}_{3}$ budget directly by surface removal of $\mathrm{O}_{3}$ and indirectly by removal of precursors such as $\mathrm{NO}_{\mathrm{x}}$ and PAN. Dry deposition velocities were altered for all species simultaneously in this sensitivity study. Increased $\mathrm{O}_{3}$ deposition is balanced largely by decreased chemical loss due to lower $\mathrm{O}_{3}$, with a small increase in production caused by lower $\mathrm{OH}$ and hence an increased lifetime for $\mathrm{NO}_{\mathrm{x}}$. Decreased chemical loss of $\mathrm{O}_{3}$ is responsible for lower $\mathrm{OH}$ formation and hence for the increased $\mathrm{CH}_{4}$ lifetime. The net impact of chemistry is very sensitive to dry deposition as the net STE flux changes only marginally in response to changes in the tropospheric burden. Note the non-linear response of the dry deposition rate to the applied increases in deposition velocity as the surface $\mathrm{O}_{3}$ abundance falls. In contrast, wet deposition does not affect $\mathrm{O}_{3}$ directly but leads to the removal of soluble species such as $\mathrm{HNO}_{3}$ and $\mathrm{H}_{2} \mathrm{O}_{2}$ which influence the availability of $\mathrm{NO}_{\mathrm{x}}$ and $\mathrm{OH}$. Increasing removal of these species by $50 \%$ causes both production and loss of $\mathrm{O}_{3}$ to fall by about $2.5 \%$, and the tropospheric burden drops proportionately. The small drop in net chemical production is balanced by reduced dry deposition, and the lifetime of $\mathrm{O}_{3}$ is little affected. However, the decrease in $\mathrm{OH}$ leads to a significant increase in the lifetime of $\mathrm{CH}_{4}$, and the $\mathrm{OH}$ response is $60-90 \%$ larger than for equivalent changes in the dry deposition rate. A non-linear response is also evident here, as a $50 \%$ reduction in wet deposition rates has twice the effect on the $\mathrm{O}_{3}$ burden and removal as a $50 \%$ increase.

The effects of temperature and humidity on oxidant chemistry are examined by applying small, globally uniform changes representative of the uncertainty in meteorological fields to the chemistry only. Increases in temperature affect chemical reaction kinetics and lead to significantly increased $\mathrm{O}_{3}$ production and loss rates, but net production and other key budget terms are largely unaffected, and the tropospheric burden drops by less than $1 \%$ for a temperature rise of $5^{\circ} \mathrm{C}$. However, the faster chemistry leads to a higher abundance of $\mathrm{OH}$, and the $\mathrm{CH}_{4}$ lifetime is reduced by almost $10 \%$ for a $5^{\circ} \mathrm{C}$ rise. This sensitivity of $\mathrm{CH}_{4}$ oxidation to temperature provides a small negative feedback on climate warming, as noted by Fiore et al. (2006), and highlights temperature as a 
Table 4. Annual ozone budgets in the FRSGC/UCI CTM: sensitivity to physical processes ${ }^{\mathrm{a}}$.

\begin{tabular}{|c|c|c|c|c|c|c|c|c|c|c|c|}
\hline \multirow[b]{2}{*}{ Run } & \multirow[b]{2}{*}{ Brief Description } & \multicolumn{6}{|c|}{$\mathrm{O}_{3}$ Budget } & \multicolumn{2}{|c|}{ Lifetimes } & \multicolumn{2}{|c|}{$\mathrm{O}_{3}$ Bias } \\
\hline & & $\mathrm{P}$ & $\mathrm{L}$ & P-L & STE & Dep & Burd & $\mathrm{O}_{3}$ & $\mathrm{CH}_{4}$ & Mean & RMS \\
\hline \multicolumn{12}{|c|}{ Effects of Stratosphere-Troposphere Exchange } \\
\hline STE1 & $50 \%$ decreased $\mathrm{O}_{3} \mathrm{STE}$ & 4183 & 3700 & 484 & 253 & 737 & 281 & 23.1 & 9.20 & -7.2 & 8.9 \\
\hline STE2 & $20 \%$ decreased $\mathrm{O}_{3}$ STE & 4126 & 3776 & 351 & 395 & 746 & 286 & 23.1 & 9.13 & -6.2 & 8.2 \\
\hline Base & Control Run & 4078 & 3842 & 236 & 519 & 756 & 290 & 23.0 & 9.07 & -5.3 & 7.8 \\
\hline STE3 & $20 \%$ increased $\mathrm{O}_{3} \mathrm{STE}$ & 4047 & 3893 & 154 & 606 & 761 & 293 & 22.9 & 9.02 & -4.6 & 7.4 \\
\hline STE4 & $50 \%$ increased $\mathrm{O}_{3} \mathrm{STE}$ & 3975 & 4013 & -38 & 812 & 776 & 299 & 22.8 & 8.90 & -3.0 & 7.1 \\
\hline \multicolumn{12}{|c|}{ Effects of Dry Deposition } \\
\hline Dry1 & $50 \%$ decreased dry dep & 4051 & 4108 & -57 & 517 & 460 & 302 & 24.1 & 8.78 & -3.2 & 7.1 \\
\hline Dry2 & $20 \%$ decreased dry dep & 4066 & 3936 & 130 & 518 & 649 & 295 & 23.5 & 8.97 & -4.5 & 7.5 \\
\hline Base & Control Run & 4078 & 3842 & 236 & 519 & 756 & 290 & 23.0 & 9.07 & -5.3 & 7.8 \\
\hline Dry3 & $20 \%$ increased dry dep & 4091 & 3761 & 329 & 520 & 850 & 285 & 22.6 & 9.16 & -5.9 & 8.2 \\
\hline Dry4 & $50 \%$ increased dry dep & 4109 & 3656 & 453 & 521 & 975 & 280 & 22.0 & 9.28 & -6.7 & 8.8 \\
\hline \multicolumn{12}{|c|}{ Effects of Wet Deposition } \\
\hline Wet1 & $50 \%$ decreased wet dep & 4302 & 4046 & 255 & 517 & 772 & 300 & 22.7 & 8.52 & -3.7 & 6.8 \\
\hline Wet2 & $20 \%$ decreased wet dep & 4146 & 3905 & 242 & 518 & 760 & 293 & 22.9 & 8.89 & -4.8 & 7.5 \\
\hline Base & Control Run & 4078 & 3842 & 236 & 519 & 756 & 290 & 23.0 & 9.07 & -5.3 & 7.8 \\
\hline Wet3 & $20 \%$ increased wet dep & 4028 & 3797 & 231 & 520 & 752 & 287 & 23.1 & 9.22 & -5.6 & .1 \\
\hline Wet4 & $50 \%$ increased wet dep & 3972 & 3745 & 227 & 521 & 749 & 285 & 23.1 & 9.40 & -6.0 & 8.4 \\
\hline \multicolumn{12}{|c|}{ Effects of Temperature on Chemistry } \\
\hline Tem1 & $5^{\circ} \mathrm{C}$ lower temperature & 3940 & 3706 & 233 & 519 & 753 & 292 & 23.9 & 9.86 & -4.8 & 7.4 \\
\hline Tem2 & $2^{\circ} \mathrm{C}$ lower temperature & 4019 & 3785 & 235 & 519 & 754 & 291 & 23.4 & 9.38 & -5.1 & 7.7 \\
\hline Base & Control Run & 4078 & 3842 & 236 & 519 & 756 & 290 & 23.0 & 9.07 & -5.3 & 7.8 \\
\hline Tem3 & $2^{\circ} \mathrm{C}$ higher temperature & 4141 & 3905 & 237 & 519 & 757 & 289 & 22.6 & 8.76 & -5.4 & 7.9 \\
\hline Tem4 & $5^{\circ} \mathrm{C}$ higher temperature & 4245 & 4005 & 239 & 519 & 760 & 288 & 22.1 & 8.32 & -5.5 & 8.1 \\
\hline \multicolumn{12}{|c|}{ Effects of Humidity on Chemistry } \\
\hline Hum1 & $20 \%$ decreased humidity & 4030 & 3730 & 300 & 516 & 815 & 309 & 24.8 & 9.69 & -2.3 & 6.0 \\
\hline Hum2 & $10 \%$ decreased humidity & 4055 & 3789 & 266 & 518 & 783 & 299 & 23.8 & 9.35 & -3.9 & 6.8 \\
\hline Base & Control Run & 4078 & 3842 & 236 & 519 & 756 & 290 & 23.0 & 9.07 & -5.3 & 7.8 \\
\hline Hum3 & $10 \%$ increased humidity & 4100 & 3891 & 209 & 520 & 731 & 282 & 22.3 & 8.82 & -6.5 & 8.8 \\
\hline Hum4 & $20 \%$ increased humidity & 4121 & 3936 & 185 & 521 & 709 & 275 & 21.6 & 8.61 & -7.6 & 9.8 \\
\hline \multicolumn{12}{|c|}{ Effects of Convection } \\
\hline Cnv1 & $50 \%$ reduced convection & 4118 & 3861 & 257 & 488 & 746 & 295 & 23.3 & 9.03 & -4.9 & 7.5 \\
\hline Cnv2 & $20 \%$ reduced convection & 4092 & 3850 & 242 & 508 & 751 & 291 & 23.1 & 9.05 & -5.2 & 7.7 \\
\hline Base & Control Run & 4078 & 3842 & 236 & 519 & 756 & 290 & 23.0 & 9.07 & -5.3 & 7.8 \\
\hline Cnv3 & $20 \%$ greater convection & 4067 & 3837 & 230 & 529 & 760 & 289 & 22.9 & 9.08 & -5.3 & 8.0 \\
\hline Cnv4 & $50 \%$ greater convection & 4055 & 3830 & 224 & 542 & 767 & 287 & 22.8 & 9.09 & -5.4 & 8.2 \\
\hline \multicolumn{12}{|c|}{ Effects of Lightning $N O_{x}$} \\
\hline Lit1 & No lightning $\mathrm{NO}_{\mathrm{x}}$ & 3460 & 3284 & 176 & 524 & 701 & 260 & 23.8 & 11.03 & -9.7 & 11.9 \\
\hline Lit2 & $50 \%$ decreased lightning & 3802 & 3593 & 209 & 521 & 731 & 277 & 23.4 & 9.84 & -7.2 & 9.5 \\
\hline Base & Control Run (5 TgN/yr) & 4078 & 3842 & 236 & 519 & 756 & 290 & 23.0 & 9.07 & -5.3 & 7.8 \\
\hline Lit3 & $50 \%$ increased lightning & 4316 & 4058 & 258 & 517 & 776 & 301 & 22.7 & 8.50 & -3.6 & 6.6 \\
\hline \multicolumn{12}{|c|}{ Effects of Alternate Treatments } \\
\hline Alt1 & Simple dry deposition & 3914 & 3419 & 495 & 522 & 1019 & 268 & 22.0 & 9.67 & -8.6 & 10.3 \\
\hline Alt2 & non-local PBL mixing & 3971 & 3799 & 172 & 519 & 691 & 288 & 23.4 & 9.20 & -5.6 & 8.1 \\
\hline Alt3 & Clear-sky photolysis & 4060 & 3813 & 248 & 521 & 770 & 283 & 22.6 & 9.07 & -6.1 & 8.7 \\
\hline Alt4 & Aerosol in photolysis & 4064 & 3830 & 233 & 519 & 753 & 290 & 23.1 & 9.13 & -5.1 & 7.7 \\
\hline Alt5 & C-profile lightning $\mathrm{NO}_{\mathrm{x}}$ & 4236 & 4003 & 232 & 517 & 750 & 304 & 23.3 & 8.72 & -3.5 & 6.6 \\
\hline
\end{tabular}

a Budgets in $\mathrm{Tg} \mathrm{yr}^{-1}$; lifetimes in days for $\mathrm{O}_{3}$ and years for $\mathrm{CH}_{4}$; biases in ppb. 
significant source of uncertainty in model-derived $\mathrm{CH}_{4}$ lifetimes, as noted by Stevenson et al. (2000). Increased humidity leads to more efficient $\mathrm{O}_{3}$ loss and greater $\mathrm{OH}$ production. Additional $\mathrm{OH}$ boosts $\mathrm{O}_{3}$ production, but this only makes up about $45 \%$ of the additional $\mathrm{O}_{3}$ loss, and net production falls. Surface deposition falls by about $6 \%$ with a $20 \%$ increase in humidity, balancing the increased chemical loss, and the $\mathrm{O}_{3}$ burden is reduced by 5\%. The global $\mathrm{O}_{3}$ burden is much more sensitive to changes in humidity than in temperature, and the $\mathrm{CH}_{4}$ lifetime is also strongly affected. Note that the uncertainty in the tropospheric water vapour burden in current climate models is about $10 \%$ (Stevenson et al., 2006), and this would introduce a $3 \%(9 \mathrm{Tg})$ variability in the $\mathrm{O}_{3}$ burden, a $3 \%$ ( 0.8 day) variability in $\mathrm{O}_{3}$ lifetime and a $3 \%$ ( 0.3 year) variability in $\mathrm{CH}_{4}$ lifetime based on these sensitivity studies.

Deep convection mixes $\mathrm{O}_{3}$-rich air from the upper troposphere down towards the surface where the $\mathrm{O}_{3}$ lifetime is shorter and lifts freshly-emitted $\mathrm{O}_{3}$ precursors into the upper troposphere where $\mathrm{O}_{3}$ production may be greater. Previous studies with and without convective transport have disagreed on the relative importance of these pathways, with Lawrence et al. (2003) finding a $12 \%$ increase in $\mathrm{O}_{3}$ burden when including convection due to the dominant effect of increased production, and Doherty et al. (2005) finding a 14\% decrease in burden as greater descent and destruction outweighed increased production. In the present study smaller changes in convection have been applied, and these were allowed to affect convective washout as well as lifting processes, unlike in the previous studies. Stronger convection leads to increased $\mathrm{O}_{3}$ production in the upper troposphere but to decreased production in the lower troposphere, where precursors are removed by greater convective lifting and washout. There is an increase in the inferred influx from the stratosphere, reflecting both convective steepening of the $\mathrm{O}_{3}$ gradient near the tropopause and direct convective penetration above the monthly-mean tracer tropopause used here. Greater tropospheric overturning leads to higher surface $\mathrm{O}_{3}$ and greater deposition, and the tropospheric burden decreases. Comparison with the wet deposition sensitivity runs presented above suggests that this is partly due to increased washout, and that the effect of lifting alone is small. These results lie midway between those presented by Lawrence et al. (2003) and Doherty et al. (2005), and highlight the large uncertainty in modelled $\mathrm{O}_{3}$ responses to convection. It is not clear if this uncertainty reflects differences in convection schemes, lightning emissions or chemical complexity, as discussed in Doherty et al. (2005), but the uncertainty is sufficiently large that this topic would be a valuable target for future model intercomparison studies.

The magnitude and distribution of lightning-produced $\mathrm{NO}_{\mathrm{x}}$ emissions are highly uncertain (e.g., Price et al., 1997) but are important for $\mathrm{O}_{3}$ due to the longer lifetime of $\mathrm{NO}_{\mathrm{x}}$ in the upper troposphere and its greater efficiency for $\mathrm{O}_{3}$ production. This sensitivity is examined here by varying the magnitude of lightning emissions from 0 to $7.5 \mathrm{TgN} / \mathrm{yr}$ in steps of $2.5 \mathrm{TgN} / \mathrm{yr}$. Increased emissions cause a large increase in production and in tropospheric burden, as seen in previous studies (Labrador et al., 2005); about 10\% of the additional $\mathrm{O}_{3}$ produced is removed by deposition, and the rest is destroyed by chemistry, contributing to a higher abundance of $\mathrm{OH}$ and to a reduced $\mathrm{CH}_{4}$ lifetime. The sensitivity of the $\mathrm{O}_{3}$ burden and the $\mathrm{CH}_{4}$ lifetime are notably larger than for the other processes considered here. The range of lightning emissions used in the ACCENT model studies, 3$8 \mathrm{TgN} / \mathrm{yr}$, would account for a $10 \%$ difference in $\mathrm{O}_{3}$ burden, a 0.7 day difference in $\mathrm{O}_{3}$ lifetime and a 1.4 year difference in $\mathrm{CH}_{4}$ lifetime between models. Note also that the study here uses vertically-uniform emission profiles for inter-cloud and cloud-to-ground lightning strokes based on Price and Rind (1992). Use of more realistic profiles based on observations (Pickering et al., 1998) (run Alt5) leads to a 25\% greater increase in $\mathrm{O}_{3}$ production and a $50 \%$ greater increase in burden for the same $5 \mathrm{TgN} / \mathrm{yr}$ emissions increase, as a greater proportion of the $\mathrm{NO}_{\mathrm{x}}$ emissions occur at high altitudes where the lifetimes of $\mathrm{O}_{3}$ and $\mathrm{NO}_{\mathrm{x}}$ are longer.

Finally, a number of additional sensitivities related to model methodology have been examined, see Table 4. The dry deposition scheme of Isaksen et al. (1985) used in some studies (e.g., Berntsen et al., 1996; Wild and Prather, 2000; Zeng and Pyle, 2005) is a simpler alternative to the resistances-in-series scheme of Wesely (1989) used here. Application of this scheme with 1-m deposition velocities from Hough (1991) leads to $30 \%$ greater $\mathrm{O}_{3}$ deposition, an additional $260 \mathrm{Tg} / \mathrm{yr}$. Faster removal of $\mathrm{NO}_{\mathrm{x}}$ suppresses production, but chemical destruction falls by a greater margin to compensate for the increased deposition. The tropospheric $\mathrm{O}_{3}$ burden is almost $10 \%$ less than in the BASE run, and underestimation of the ozonesonde measurements suggest that the deposition rate with this scheme is too high. However, the lack of good observational constraints on deposition prevents this from being determined uniquely. The deposition rate is also reduced by application of a non-local boundary layer mixing scheme (Holtslag and Boville, 1993) in place of the simple hourly bulk-mixing used in the BASE run. Less efficient vertical mixing leads to stronger near-surface gradients and reduced deposition of $\mathrm{O}_{3}$, but a smaller proportion of $\mathrm{NO}_{\mathrm{x}}$ escapes into the free troposphere, so chemical production is suppressed. The net effect of these changes on the global burden is small, less than $1 \%$.

A major source of uncertainty not considered here is in the calculation of photolysis rates. A number of different methods are currently used, ranging in complexity from tabulated rates based on climatological conditions to fully-interactive schemes accounting for absorption and scattering of aerosol and cloud particles calculated on-line. A simple test removing all cloud cover in the interactive Fast-J scheme used here (Wild et al., 2000) indicates that the global budget of $\mathrm{O}_{3}$ is relatively insensitive to cloud cover. However, global $\mathrm{O}_{3}$ production at the surface is $15 \%$ higher without cloud cover, 


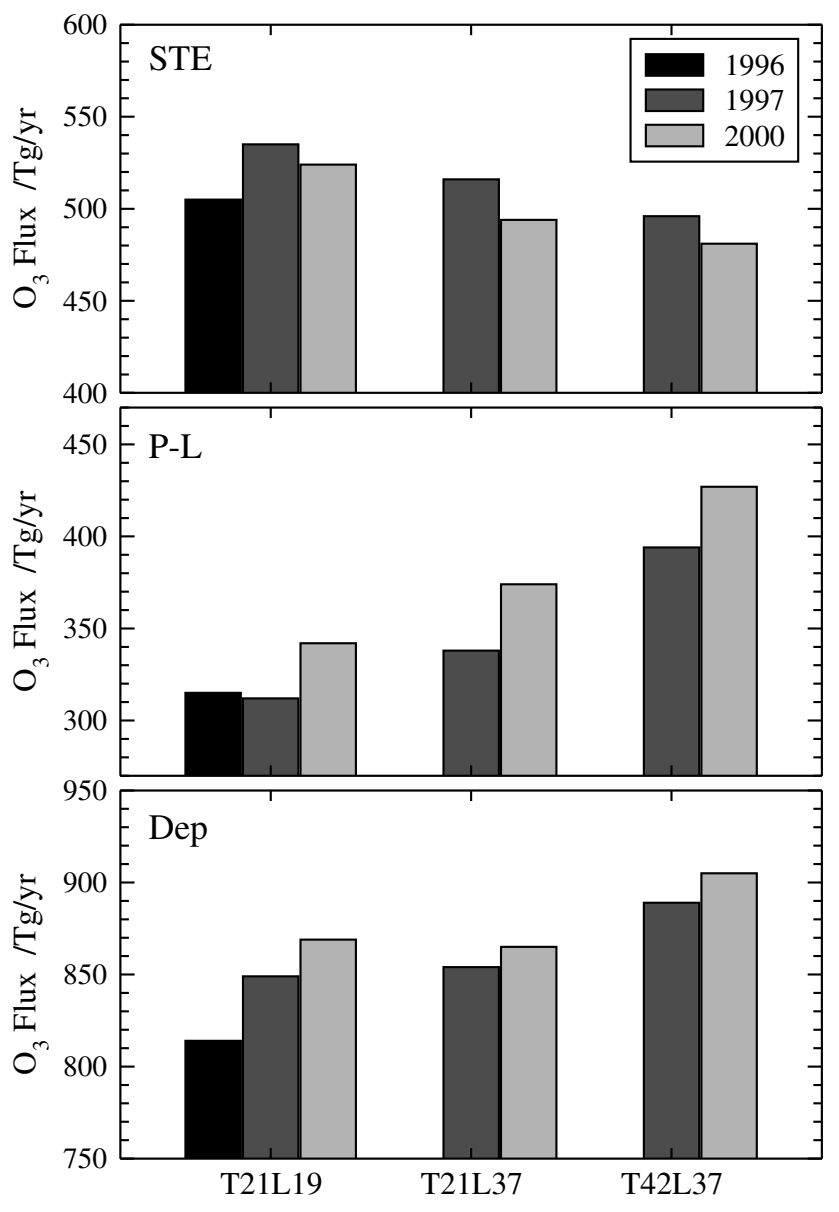

Fig. 4. Effects of meteorology and model resolution on the annual flux of $\mathrm{O}_{3}$ through stratosphere-troposphere exchange (STE), net chemistry (P-L) and surface deposition (Dep).

balanced by lower production in the upper troposphere, and regional and seasonal differences can be much larger. The global $\mathrm{O}_{3}$ burden change of $2.5 \%$ is comparable to the $3-5 \%$ changes found by Liu et al. (2006), but is clearly smaller than the $8-12 \%$ changes found by Tie et al. (2003), suggesting that the impacts may depend on details of the cloud scheme used. Inclusion of monthly-mean aerosol fields for the scattering code similarly lead to regional differences in $\mathrm{O}_{3}$ production, but the global impacts appear to be small.

\subsection{Sensitivity to meteorology and resolution}

Differences in meteorological data may affect the $\mathrm{O}_{3}$ budget through self-consistent variations in the physical processes considered in Sect. 4.2. Meteorological data from the ECMWF-IFS model for 1997 and 2000 are compared with the fields for 1996 used in this study, and the impact on the $\mathrm{O}_{3}$ budget is shown in Table 5 and in Fig. 4. The CTM is run at T21L19 with each meteorology, and is additionally run at T21L37 and T42L37 to test the effects of doubled verti- cal and horizontal resolution. The lower resolution fields are derived from the parent T42L37 data so that advective and convective mass fluxes are the same across the different resolutions. Precursor emissions are taken from IIASA for closer comparison with the ACCENT studies, and the same emissions are used for each year. For this sensitivity study only, total lightning $\mathrm{NO}_{\mathrm{x}}$ emissions are constrained to $6.5 \mathrm{TgN} / \mathrm{yr}$ and are distributed vertically following the profiles of Pickering et al. (1998); the geographical distribution of the emissions differs from year to year following the occurrence of deep convection events. Differences in $\mathrm{O}_{3}$ burden and lifetime between the different years are small, but differences in STE, deposition and chemistry reach 7-8\%. The lifetime of $\mathrm{CH}_{4}$ is $5 \%$ longer in 1997 than in 2000, suggesting that $\mathrm{OH}$ levels are significantly lower and reflecting shifts in humidity and convection during the 1997-1998 El Niño period (Chandra et al., 1998; Sudo et al., 2001). The chemical production of $\mathrm{O}_{3}$ is lower in 1997, and influx from the stratosphere is greater. These results are in good qualitative agreement with those of Zeng and Pyle (2005) who examined the evolution of the $\mathrm{O}_{3}$ budget between 1990 and 2001 with a global climate model. The magnitude of this interannual variability indicates that model intercomparisons focussed on differences due to chemical or dynamical schemes should recommend use of the same meteorological fields.

Model $\mathrm{O}_{3}$ budgets are sensitive to the horizontal and vertical resolution used, both through their effects on transport and mixing processes and through their impacts on $\mathrm{O}_{3}$ chemistry from the spatial averaging of emissions (e.g., Chatfield and Delany, 1990). At the highest resolution used here, T42L37, there is a significant reduction in STE $(8 \%$, $40 \mathrm{Tg} / \mathrm{yr}$ ) compared with T21L19 due to better resolution of the tropopause and there is an increase in surface deposition $(5 \%, 40 \mathrm{Tg} / \mathrm{yr})$. Increased net chemical production $(25 \%, 80 \mathrm{Tg} / \mathrm{yr})$ balances the budget, but there is a $2-4 \%$ drop in the $\mathrm{O}_{3}$ burden. The magnitude of these effects is highly consistent for 1997 and 2000 meteorology, and confirms the results of previous studies (von Kuhlmann et al., 2003; Wild and Prather, 2006). It is worth noting that some studies have found greater STE at higher horizontal resolution (Kentarchos et al., 2001; van Noije et al., 2004), although this may be strongly influenced by excessive vertical motions in the lower stratosphere associated with the assimilation methods used during generation of meteorological reanalyses (Douglass et al., 1996; van Noije et al., 2006). The changes due to resolution seen here are similar in magnitude to those with different meteorological fields, but are systematic in nature. Increased vertical resolution has relatively little effect on gross chemical production or surface deposition, but accounts for at least half of the decrease in STE and for about one third of the increase in net production. Increased horizontal resolution dominates the changes in deposition and gross chemical production due to better localisation of boundary layer $\mathrm{O}_{3}$, its production and convection, and better resolution of the tropopause region leads to an additional 
Table 5. Annual ozone budgets in the FRSGC/UCI CTM: sensitivity to meteorology and resolution ${ }^{\mathrm{a}}$.

\begin{tabular}{|c|c|c|c|c|c|c|c|c|c|c|c|c|c|}
\hline \multirow[b]{2}{*}{ Run } & \multirow[b]{2}{*}{ Description } & \multicolumn{2}{|c|}{ Meteorological Data } & \multicolumn{6}{|c|}{$\mathrm{O}_{3}$ Budget } & \multicolumn{2}{|c|}{ Lifetimes } & \multicolumn{2}{|c|}{$\mathrm{O}_{3}$ Bias } \\
\hline & & Resolution & Year & $\mathrm{P}$ & $\mathrm{L}$ & P-L & STE & Dep & Burd & $\mathrm{O}_{3}$ & $\mathrm{CH}_{4}$ & Mean & RMS \\
\hline Met96 & IFS 1996 data & T21 L19 & 1996 & 5247 & 4932 & 315 & 505 & 814 & 342 & 21.7 & 8.38 & 2.1 & 5.0 \\
\hline Met97 & IFS 1997 data & T21 L19 & 1997 & 4975 & 4663 & 312 & 535 & 849 & 336 & 22.2 & 8.79 & 0.9 & 5.9 \\
\hline Met97L & -37 levels & T21 L37 & 1997 & 5103 & 4766 & 338 & 516 & 854 & 340 & 22.1 & 8.54 & 2.3 & 6.0 \\
\hline Met97R & - T42 resolution & T42 L37 & 1997 & 4982 & 4588 & 394 & 496 & 889 & 331 & 22.0 & 8.89 & 1.5 & 5.3 \\
\hline Met00 & IFS 2000 data & T21 L19 & 2000 & 5314 & 4972 & 342 & 524 & 869 & 345 & 21.5 & 8.02 & 2.4 & 5.6 \\
\hline Met00L & -37 levels & T21 L37 & 2000 & 5310 & 4935 & 374 & 494 & 865 & 341 & 21.5 & 8.10 & 2.1 & 5.3 \\
\hline Met00R & - T42 resolution & T42 L37 & 2000 & 5160 & 4734 & 427 & 481 & 905 & 331 & 21.4 & 8.45 & 1.7 & 4.3 \\
\hline
\end{tabular}

a Budgets in $\mathrm{Tg} \mathrm{yr}^{-1}$; lifetimes in days for $\mathrm{O}_{3}$ and years for $\mathrm{CH}_{4}$; biases in ppb.

reduction in STE. Although the mean tropospheric lifetime of $\mathrm{O}_{3}$ is only marginally affected by increased resolution, the chemical lifetime of $\mathrm{CH}_{4}$ is substantially increased, by as much as $5 \%$ for the 2000 case, reflecting lower $\mathrm{OH}$ and $\mathrm{O}_{3}$ production at higher resolution.

\subsection{Examining inter-model variability}

To what extent do the sensitivities examined here account for the variability in published model budgets seen in Table 1 ? The results of these sensitivity studies and of earlier published studies are shown in Fig. 5. The variability is examined in two different parameter spaces which summarize the fate of $\mathrm{O}_{3}$ and the abundance of $\mathrm{OH}$, following Stevenson et al. (2006). Results from published model studies and from individual models from the ACCENT model intercomparison are shown in Figs. 5a and b, and results from the sensitivity studies over part of these parameter spaces are shown in Figs. 5c and d. The sensitivities examined here do not reflect the same level of uncertainty in the different variables, but are intended to be loosely comparable so that the relative importance of different processes is evident.

Differences in the abundance and fate of $\mathrm{O}_{3}$ are revealed by the relationship between the tropospheric burden and the lifetime of $\mathrm{O}_{3}$ to chemical removal and deposition and are shown in Fig. 5a. Inclusion of hydrocarbon chemistry and increased surface emissions lead to higher burdens and shorter lifetimes, but cannot account for the large spread in burden (274-407 Tg), lifetime (17-28 years) and removal rate (4500-7600 Tg/yr) seen in the ACCENT studies where emissions varied little. Figure $5 \mathrm{c}$ suggests that differences in humidity and in surface deposition may make important contributions to this variation, as they affect the $\mathrm{O}_{3}$ burden and lifetime without changing gross tropospheric removal significantly. A $10 \%$ variation in humidity and a $200 \mathrm{Tg} / \mathrm{yr}$ variation in dry deposition, as seen in the ACCENT studies (Stevenson et al., 2006), could each account for $9 \mathrm{Tg}$ in $\mathrm{O}_{3}$ burden and 1 day in $\mathrm{O}_{3}$ lifetime. Variations in tempera- ture and convection have a similar but smaller effect. Wet deposition and STE lead to changes in the gross removal of $\mathrm{O}_{3}$, but the scatter in this dimension is strongly influenced by emissions. Lightning $\mathrm{NO}_{\mathrm{x}}$ emissions varied between 3 and $8 \mathrm{Tg} / \mathrm{yr}$ for the ACCENT models and may account for $30 \mathrm{Tg}$ in $\mathrm{O}_{3}$ burden and $500 \mathrm{Tg} / \mathrm{yr}$ in $\mathrm{O}_{3}$ removal. Isoprene emissions varied between 220 and $630 \mathrm{TgC} / \mathrm{yr}$, and may thus account for $20 \mathrm{Tg}$ in $\mathrm{O}_{3}$ burden and $650 \mathrm{Tg} / \mathrm{yr}$ in $\mathrm{O}_{3}$ removal. Differences in meteorological data reflecting interannual variability between the three years studied here introduce less variability, about $5 \mathrm{Tg}$ in $\mathrm{O}_{3}$ burden and 0.5 days in $\mathrm{O}_{3}$ lifetime, although increased resolution may lead to a 5$15 \mathrm{Tg}$ reduction in burden. However, the sensitivity studies performed here clearly do not account for the full variability in $\mathrm{O}_{3}$ budgets seen in the ACCENT runs, and it is likely that differences in chemical mechanisms, in model dynamics, and in the reanalysis methods used to generate the meteorological data also make large contributions to this variability.

The relationship between the chemical loss of $\mathrm{O}_{3}$, governing the source of $\mathrm{OH}$, and the lifetime of $\mathrm{CH}_{4}$, controlled by $\mathrm{OH}$, is shown in Fig. 5b. The variability in this relationship is more restricted, and most points lie close to a single line, as processes that increase $\mathrm{O}_{3}$ production and loss are associated with a higher level of $\mathrm{OH}$ and hence with a shorter $\mathrm{CH}_{4}$ lifetime. Surface emissions of isoprene have a significantly different effect, however, as greater $\mathrm{OH}$ formation from higher $\mathrm{O}_{3}$ production and loss is outweighed by the direct removal of $\mathrm{OH}$ that initiates hydrocarbon oxidation, and thus $\mathrm{CH}_{4}$ lifetime increases with higher isoprene emissions as other studies have noted (von Kuhlmann et al., 2004). Ozone loss and $\mathrm{CH}_{4}$ lifetime are systematically lower in model studies omitting higher hydrocarbons. The mean chemical lifetime of $\mathrm{CH}_{4}$ from the ACCENT studies is 9.8 years, close to the 9.6 years recommended by Prather and Ehhalt (2001), but the variability is large, $6.9-15.2$ years. This variability implies a large uncertainty in $\mathrm{CH}_{4}$ emissions, as the global $\mathrm{CH}_{4}$ burden is relatively well constrained. The variation in lightning 

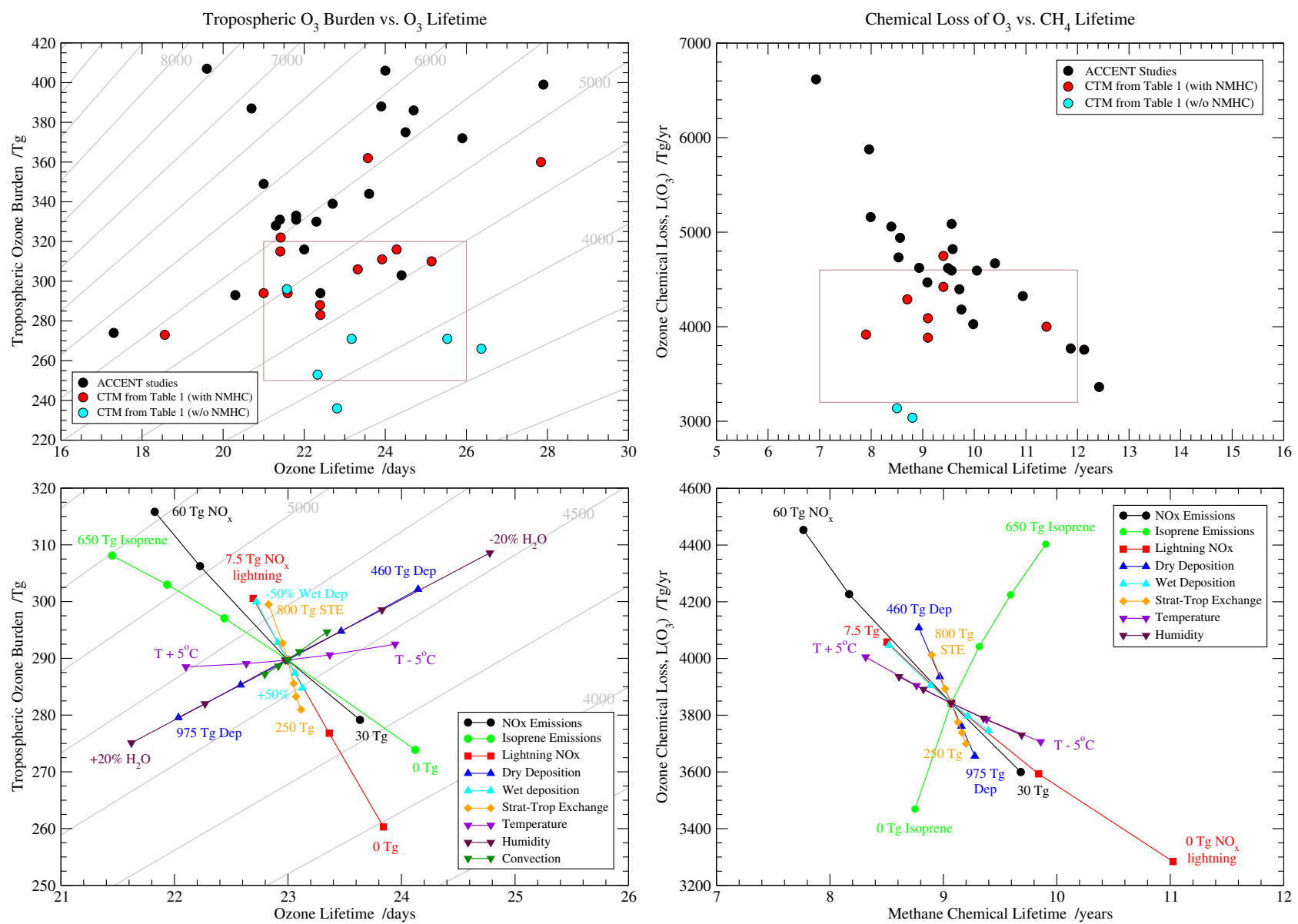

Fig. 5. The relationship between the tropospheric burden of $\mathrm{O}_{3}$ and its lifetime to chemical removal and deposition (left panels, a and c) and between the chemical removal of $\mathrm{O}_{3}$ and the chemical lifetime of $\mathrm{CH}_{4}$ (right panels, $\mathbf{b}$ and $\mathbf{d}$ ). The upper panels (a and $\mathbf{b}$ ) show results from published studies summarized in Table 1 and the lower panels ( $\mathrm{c}$ and d) show the results of sensitivity studies listed in Table 3. Tropospheric $\mathrm{O}_{3}$ removal rates versus chemistry and deposition are shown as diagonal lines in the left panels (labelled in Tg/yr). For ease of comparison the domain of the sensitivity studies shown in the lower panels $\mathrm{c}$ and $\mathrm{d}$ is highlighted in the upper panels with a box.

$\mathrm{NO}_{\mathrm{x}}$ emissions may account for almost 1.5 years in the $\mathrm{CH}_{4}$ lifetime, but differences in temperature, humidity, wet and dry deposition, and STE also contribute significantly to this variability. The abundance of $\mathrm{OH}$ is very sensitive to the chemistry and photolysis schemes used, and the effects of these have not been examined in this study. However, determination of the climate impacts of $\mathrm{CH}_{4}$ and other trace gases depends on a reliable quantification of chemical removal by $\mathrm{OH}$, and the large variability seen in the ACCENT studies suggests that further work is needed to reduce the uncertainty in current models.

To estimate the contribution of the processes examined here to the variability in the budget terms from the ACCENT intercomparison, the $\mathrm{O}_{3}$ budget terms for each model are standardized by applying corrections based on the sensitivities derived with the FRSGC/UCI CTM, see Table 6. A sensitivity factor for the change in each of these budget terms
Table 6. Budget terms from the ACCENT model intercomparison corrected for different surface and lightning emissions, dry deposition and STE fluxes.

\begin{tabular}{lccc}
\hline & $\begin{array}{c}\mathrm{O}_{3} \text { Prod } \\
(\mathrm{Tg} / \mathrm{yr})\end{array}$ & $\begin{array}{c}\mathrm{O}_{3} \text { Loss } \\
(\mathrm{Tg} / \mathrm{yr})\end{array}$ & $\begin{array}{c}\mathrm{CH}_{4} \text { Lifetime } \\
\text { (years) }\end{array}$ \\
\hline ACCENT study & $5110 \pm 606$ & $4668 \pm 727$ & $9.79 \pm 1.74$ \\
Standardization: All & $5110 \pm 506$ & $4668 \pm 518$ & $9.71 \pm 1.33$ \\
\multicolumn{4}{c}{ Standardization of Separate Processes } \\
$\mathrm{NO}_{\mathrm{x}}$ emissions only & $5110 \pm 596$ & $4668 \pm 721$ & $9.78 \pm 1.72$ \\
Isoprene emissions only & $5110 \pm 539$ & $4668 \pm 667$ & $9.78 \pm 1.73$ \\
Lightning NO $\mathrm{N}_{\mathrm{x}}$ only & $5110 \pm 563$ & $4668 \pm 656$ & $9.72 \pm 1.42$ \\
Dry Deposition only & $5110 \pm 608$ & $4668 \pm 664$ & $9.78 \pm 1.69$ \\
STE only & $5110 \pm 621$ & $4668 \pm 682$ & $9.78 \pm 1.72$ \\
\hline
\end{tabular}


with respect to STE, dry deposition, lightning and surface emissions is derived from Table 4, and a correction is then applied for each model by scaling the sensitivity factor by the deviation from the ACCENT ensemble mean. As an example, the sensitivity factor for $\mathrm{O}_{3}$ production from lightning $\mathrm{NO}_{\mathrm{x}}$ emissions is $150 \mathrm{Tg} / \mathrm{TgN}$ based on run Alt5 in Table 4, and the ensemble mean lightning emission is $5.7 \mathrm{TgN} / \mathrm{yr}$, so the correction for gross $\mathrm{O}_{3}$ production for a model with 5.0 TgN/yr lightning $\mathrm{NO}_{\mathrm{x}}$ is $+105 \mathrm{Tg} / \mathrm{yr}$. Note that this simple approach assumes a linear response and therefore the ensemble mean production and loss terms remain unaltered. However, this standardization leads to a reduction in the $1 \sigma$ variability of $100 \mathrm{Tg} / \mathrm{yr}$ for production and $200 \mathrm{Tg} / \mathrm{yr}$ for loss when applied to all budget terms considered here, and the difference between the outlying models is reduced by more than $35 \%$. The largest contributions to this reduced variability in production come from standardizing the isoprene emissions and lightning $\mathrm{NO}_{\mathrm{x}}$, while for chemical loss there is also a large impact from standardizing deposition. There is a small decrease in the mean $\mathrm{CH}_{4}$ lifetime as corrections are applied to $\mathrm{CH}_{4}$ loss rates, but the $1 \sigma$ variability in the $\mathrm{CH}_{4}$ lifetime is reduced by about $25 \%$, from 1.7 to 1.3 years, and the difference between the outlying models is also reduced by $25 \%$. Lightning $\mathrm{NO}_{\mathrm{x}}$ emissions make the largest contribution to this reduced variability. Although this standardization is approximate, it demonstrates that the biases imposed by the treatment of these processes are systematic, and that the differences between models would be reduced in more tightly constrained studies.

\section{Conclusions}

This study has examined how the tropospheric $\mathrm{O}_{3}$ budget calculated in global CTMs has evolved over the past decade and has explored the sensitivity of the key budget terms to variability in precursor emissions, physical processes and meteorology. Large differences apparent in early CTM studies reflect overestimation of stratosphere-troposphere exchange and omission of hydrocarbon chemistry. The increases in $\mathrm{O}_{3}$ production and tropospheric burden in more recent studies are principally due to use of higher surface emissions of $\mathrm{NO}_{\mathrm{x}}$ and isoprene. The higher $\mathrm{NO}_{\mathrm{x}}$ emissions largely reflect a better understanding of sources and emission factors, while higher isoprene emissions suggest greater confidence in the large emission estimates within the modelling community. Increases in these emissions alone lead to an increase in $\mathrm{O}_{3}$ production of $1100 \mathrm{Tg} / \mathrm{yr}$ in the FRSGC/UCI CTM, accounting for about $66 \%$ of the increase in production seen between the IPCC-TAR and ACCENT studies. Recent analysis by Wu et al. (2007) has shown similar results. Comparison with ozonesonde measurements suggests that precursor emissions used in earlier studies were too low, and that $\mathrm{O}_{3}$ distributions are reproduced better with recent IIASA emissions data.
The burden of $\mathrm{O}_{3}$ in the troposphere in CTMs has increased from around $300 \mathrm{Tg}$ to around $340 \mathrm{Tg}$ following the increase in precursor emissions, but is strongly influenced by the tropopause definition used. Comparison of three $\mathrm{O}_{3}$ climatologies with seven different tropopause definitions suggests that as much as $\pm 15 \%$ of the variability in the burden may be due to the choice of tropopause. Recent model assessments have recommended use of an $\mathrm{O}_{3}$ tracer tropopause of $150 \mathrm{ppb}$ (Prather and Ehhalt, 2001), and this provides a robust definition consistent with that of a dynamical tropopause based on PV, giving a tropospheric burden of $335 \pm 10 \mathrm{Tg}$ with the monthly-mean measurement climatologies used here. The mean burden from the ACCENT model intercomparison is $344 \mathrm{Tg}$, close to this value, but the $1 \sigma$ variability remains large, $39 \mathrm{Tg}$, even with consistent use of the $150 \mathrm{ppb} \mathrm{O}_{3}$ tracer tropopause, highlighting substantial differences in $\mathrm{O}_{3}$ distribution between the models. Further exploration of the sensitivity of the mean burden and the cross-tropopause flux to the choice of upper boundary for $\mathrm{O}_{3}$ and to the reanalysis method used in generating the meteorology would be valuable.

Sensitivity studies have been performed to examine how differences in key model processes might account for the difference in $\mathrm{O}_{3}$ budget terms seen in the relatively wellconstrained ACCENT model intercomparison. The magnitude and vertical distribution of lightning $\mathrm{NO}_{\mathrm{x}}$ emissions is shown to be a major source of uncertainty, and the 3$8 \mathrm{TgN} / \mathrm{yr}$ range in the ACCENT study may account for a $10 \%$ difference in tropospheric ozone burden (about $30 \mathrm{Tg}$ ) and a 1.4 year difference in $\mathrm{CH}_{4}$ lifetime. This accounts for about $10 \%$ of the variability in the ACCENT $\mathrm{O}_{3}$ budgets and almost $20 \%$ of the variability in the $\mathrm{CH}_{4}$ lifetime. Processes affecting the $\mathrm{O}_{3}$ distribution, such as dry deposition, STE, and convection, and those affecting chemical production and loss, such as temperature, humidity, photolysis and wet removal of precursors, also have an important role and may account for much of the year-to-year variability in the budgets of $\mathrm{O}_{3}$ and $\mathrm{CH}_{4}$. The uncertainty in these processes is not well characterised, but dry deposition, STE and surface and lightning emissions account for about $25 \%$ of the model variability in the ACCENT intercomparison. The large spread in $\mathrm{CH}_{4}$ lifetime suggests that the climate response of changes in $\mathrm{O}_{3}$ precursors in current models may differ substantially. Tighter constraints on lightning $\mathrm{NO}_{\mathrm{x}}$ emissions and meteorological fields would allow future model intercomparisons to focus more closely on the impacts of different chemistry schemes and different parameterizations of convection and mixing which are difficult to discern from recent studies.

Further development of CTMs with greater chemical detail, better treatment of scavenging and aerosol processes and finer resolution of small-scale processes is expected to lead to refinement of the $\mathrm{O}_{3}$ budget terms explored here. As improved parameterizations of the key processes become available, widely-differing models should start to converge on the same budget terms, with differences driven 
only by interannual variability in meteorology and emissions. Tightly-constrained model intercomparisons will continue to be valuable in identifying those areas where significant differences exist between models, and should ultimately allow a more rigorous quantification of uncertainty in the key budget terms. Important targets for future intercomparisons should be the distribution and speciation of $\mathrm{NO}_{\mathrm{y}}$ and the treatment of oxygenated VOCs, both of which have been implicated in the ACCENT studies as major sources of uncertainty (Dentener et al., 2006b; Shindell et al., 2006). Observational constraints on the key terms in the $\mathrm{O}_{3}$ budget remain very poor, and improved estimates based on satellite or in-situ measurements would be valuable.

Acknowledgements. The author is grateful for discussions with D. Jacob (Harvard) and D. Stevenson (University of Edinburgh) which initiated this work and for further discussions with $\mathrm{S}$. Wu (Harvard), and would like to thank all those who contributed to the ACCENT model intercomparison. The study was supported by the Frontier Research Center for Global Change of the Japan Agency for Marine-Earth Science and Technology (JAMSTEC), Japan, and by the NERC QUEST project in the UK.

Edited by: A. Stohl

\section{References}

Berntsen, T., Isaksen, I. S. A., Wang, W.-C., and Liang, X.-Z.: Impacts of increased anthropogenic emissions in Asia on tropospheric ozone and climate. A global 3-D model study, Tellus, 48B, 13-32, 1996.

Bethan, S., Vaughan, G., and Reid, S. J.: A comparison of ozone and thermal tropopause heights and the impact of tropopause definition on quantifying the ozone content of the troposphere, Q. J. Roy. Meteor. Soc., 122, 929-944, 1996.

Bey, I., Jacob, D. J., Yantosca, R. M., et al.: Global modelling of tropospheric chemistry with assimilated meteorology: Model description and evaluation, J. Geophys. Res., 106(D19), 23 07323 095, 2001.

Chandra, S., Ziemke, J. R., Min, W., and Read, W. G.: Effects of 1997-1998 El Niño on tropospheric ozone and water vapor, Geophys. Res. Lett., 25, 3867-3870, 1998.

Chatfield, R. B. and Delany, A. C.: Convection links biomass burning to increased tropical ozone: However, models will tend to overpredict $\mathrm{O}_{3}$, J. Geophys. Res., 95, 18 473-18 488, 1990.

Crutzen, P. J., Lawrence, M. G., and Pöschl, U.: On the background photochemistry of tropospheric ozone, Tellus, 51A-B, 123-146, 1999.

Dentener, F., Stevenson, D., Cofala, J., Mechler, R., Amann, M., Bergamaschi, P., Raes, F., and Derwent, R.: The impact of air pollutant and methane emission controls on tropospheric ozone and radiative forcing: CTM calculations for the period 19902030, Atmos. Chem. Phys., 5, 1731-1755, 2005, http://www.atmos-chem-phys.net/5/1731/2005/.

Dentener, F., Stevenson, D., Ellingsen, K., et al.: The global atmospheric environment for the next generation, Environ. Sci. Technol., 40, 3586-3594, doi:10.1021/es0523845, 2006a.
Dentener, F., Drevet, J., Lamarque, J. F., et al.: Nitrogen and sulfur deposition on regional and global scales: A multimodel evaluation, Global Biogeochem. Cycles, 20, GB2020, doi:10.1029/2005GB002672, 2006b.

Doherty, R. M., Stevenson, D. S., Collins, W. J., and Sanderson, M. G.: Influence of convective transport on tropospheric ozone and its precursors in a chemistry-climate model, Atmos. Chem. Phys., 5, 3205-3218, 2005, http://www.atmos-chem-phys.net/5/3205/2005/.

Douglass, A. R., Weaver, C. J., Rood, R. B., and Coy, L.: A threedimensional simulation of the ozone annual cycle using winds from a data assimilation system, J. Geophys. Res., 101, 14631474, 1996.

Fiore, A. M., Horowitz, L. W., Dlugokencky, E. J., and West, J. J.: Impact of meteorology and emissions on methane trends, 1990-2004, Geophys. Res. Lett., 33, L12809, doi:10.1029/2006GL026199, 2006.

Fortuin, J. P. F. and Kelder, H.: An ozone climatology based on ozonesonde and satellite measurements, J. Geophys. Res., 103, 31 709-31 734, 1998.

Gauss, M., Myhre, G., Pitari, G., et al.: Radiative forcing in the 21 st century due to ozone changes in the troposphere and lower stratosphere, J. Geophys. Res., 108, 4292 , doi:10.1029/2002JD002624, 2003.

Gettelman, A., Holton, J. R., and Rosenlof, K. H.: Mass fluxes of $\mathrm{O}_{3}, \mathrm{CH}_{4}, \mathrm{~N}_{2} \mathrm{O}$ and $\mathrm{CF}_{2} \mathrm{Cl}_{2}$ in the lower stratosphere calculated from observational data, J. Geophys. Res., 102, 19 149-19159, 1997.

Guenther, A., Hewitt, C. N., Erickson, D., et al.: A global model of natural volatile organic compound emissions, J. Geophys. Res., 100, 8873-8892, 1995.

Hauglustaine, D. A., Brasseur, G. P., Walters, S., Rasch, P. J., Müller, J.-F., Emmons, L. K., and Carroll, M. A.: MOZART, a global chemical transport model for ozone and related chemical tracers: 2. Model results and evaluation, J. Geophys. Res., 103, 28 291-28 335, 1998.

Hauglustaine, D. A., Hourdin, F., Jourdain, L., Filiberti, M.-A., Walters, S., Lamarque, J.-F., and Holland, E. A.: Interactive chemistry in the Laboratoire de Météorologie Dynamique general circulation model: Description and background tropospheric chemistry evaluation, J. Geophys. Res., 109, D04314, doi:10.1029/2003JD003957, 2004.

Holloway, T., Fiore, A. M., and Galanter-Hastings, M.: Intercontinental transport of air pollution: Will emerging science lead to a new hemispheric treaty?, Environ. Sci. Technol., 37, 4535-4542, 2003.

Holtslag, A. A. M. and Boville, B. A.: Local versus nonlocal boundary layer diffusion in a global climate model, J. Climate, 6, 1825$1842,1993$.

Horowitz, L. W., Walters, S., Mauzerall, D. L., et al.: A global simulation of tropospheric ozone and related tracers: Description and evaluation of MOZART, version 2, J. Geophys. Res., 108(D24), 4784, doi:10.1029/2002JD002853, 2003.

Hough, A. M.: Development of a two-dimensional global tropospheric model: Model chemistry, J. Geophys. Res., 96, 7325$7362,1991$.

Houweling, S., Dentener, F., and Lelieveld, J.: The impact of nonmethane hydrocarbon compounds on tropospheric photochemistry, J. Geophys. Res., 103, 10 673-10 696, 1998. 
Isaksen, I. S. A., Hov, Ø., Penkett, S. A., and Semb, A.: Model analysis of the measured concentration of organic gases in the Norwegian Arctic, J. Atmos. Chem., 3, 3-27, 1985.

Kentarchos, A. S., Roelofs, G. J., and Lelieveld, J.: Altitude dependence of tropospheric ozone over the Northern Hemisphere during 1996, simulated with a chemistry-general circulation model at two different resolutions, J. Geophys. Res., 106, 17453$17469,2001$.

Labrador, L. J., von Kuhlmann, R., and Lawrence, M. G.: The effects of lightning-produced $\mathrm{NO}_{\mathrm{x}}$ and its vertical distribution on atmospheric chemistry: sensitivity simulations with MATCHMPIC, Atmos. Chem. Phys., 5, 1815-1834, 2005, http://www.atmos-chem-phys.net/5/1815/2005/.

Lawrence, M. G., Crutzen, P. J., Rasch, P. J., Eaton, B. E., and Mahowald, N. M.: A model for studies of tropospheric photochemistry: description, global distributions and evaluation, J. Geophys. Res., 104, 26 245-26 277, 1999.

Lawrence, M. G., von Kuhlmann, R., and Salzmann, M.: The balance of effects of deep convective mixing on tropospheric ozone, Geophys. Res. Lett., 30(18), 1940, doi:10.1029/2003GL017644, 2003.

Lelieveld, J. and Dentener, F. J.: What controls tropospheric ozone? J. Geophys. Res., 105, 3531-3551, 2000.

Lelieveld, J. and van Dorland, R.: Ozone chemistry changes in the troposphere and consequent radiative forcing of climate, in: Atmospheric Ozone as a Climate Gas, edited by: Wang, W. C. and Isaksen, I. S. A., NATO ASI Series I, Vol. 32, Springer-Verlag, Berlin, 1995.

Levy II, H., Kasibhatla, P. S., Moxim, W. J., Klonecki, A. A., Hirsch, A. I., Oltmans, S. J., and Chameides, W. L.: The global impact of human activity on tropospheric ozone, Geophys. Res. Lett., 24, 791-794, 1997.

Li, D. and Shine, K. P.: A 4-Dimensional Ozone Climatology for UGAMP Models, UGAMP Internal Report No. 35, April 1995.

Liu, H., Crawford, J. H., Pierce, R. B., et al.: Radiative effect of clouds on tropospheric chemistry in a global threedimensional chemical transport model, J. Geophys. Res., 111, D20303, doi:10.1029/2005JD006403, 2006.

Logan, J. A.: An analysis of ozonesonde data for the troposphere: Recommendations for testing 3-D models, and development of a gridded climatology for tropospheric ozone, J. Geophys. Res., 104, 16 115-16 149, 1999.

Mallet, V. and Sportisse, B.: Uncertainty in a chemistry-transport model due to physical parameterizations and numerical approximations: An ensemble approach applied to ozone modeling, J. Geophys. Res., 111, D01302, doi:10.1029/2005JD006149, 2006.

McLinden, C. A., Olsen, S., Hannegan, B., Wild, O., Prather, M. J., and Sundet, J.: Stratospheric ozone in 3-D models: A simple chemistry and the cross-tropopause flux, J. Geophys. Res., 105, 14 653-14 665, 2000.

Mickley, L. J., Murti, P. P., Jacob, D. J., Logan, J. A., Rind, D., and Koch, D.: Radiative forcing from tropospheric ozone calculated with a unified chemistry-climate model, J. Geophys. Res., 104, $30153-30172,1999$.

Müller, J.-F. and Brasseur, G.: IMAGES: A three-dimensional chemical transport model of the global troposphere, J. Geophys. Res., 100(D8), 16 445-16490, 1995.

Murphy, D. M. and Fahey, D. W.: An estimate of the flux of stratospheric reactive nitrogen and ozone into the troposphere, J. Geo- phys. Res., 99, 5325-5332, 1994.

Olivier, J. G. J. and Berdowski, J. J. M.: Global emissions sources and sinks, in: The Climate System, edited by: Berdowski, J. J. M., Guicherit, R., and Heij, B. J., A. A. Balkemer Publishers, Lisse, The Netherlands, pp. 33-78, 2001.

Olivier, J. G. J., Bouwman, A. F., van der Maas, C. W. M., et al.: Description of EDGAR Version 2.0, RIVM/TNO report 771060 002, RIVM, Bilthoven, December 1996.

Olsen, S. C., McLinden, C. A., and Prather, M. J.: The stratospheric $\mathrm{N}_{2} \mathrm{O}-\mathrm{NO}_{\mathrm{y}}$ system: Testing uncertainties in a 3-D framework, J. Geophys. Res., 106, 28 771-28 784, 2001.

Park, R. J., Pickering, K. E., Allen, D. J., Stenchikov, G. L., and Fox-Rabinovitz, M. S.: Global simulation of tropospheric ozone using the University of Maryland Chemical Transport Model (UMD-CTM): 1. Model description and evaluation, J. Geophys. Res., 109, D09301, doi:10.1029/2003JD004266, 2004.

Pickering, K. E., Wang, Y., Tao, W.-K., Price, C., and Müller, J.F.: Vertical distributions of lightning $\mathrm{NO}_{\mathrm{x}}$ for use in regional and global chemical transport models, J. Geophys. Res., 103(D23), 31 203-31 216, doi:10.1029/98JD02651, 1998.

Pöschl, U., von Kuhlmann, R., Poisson, N., and Crutzen, P. J.: Development and intercomparison of condensed isoprene oxidation mechanisms for global atmospheric modeling, J. Atmos. Chem., 37, 29-52, 2000.

Prather, M. J. and Ehhalt, D.: Atmospheric Chemistry and Greenhouse Gases, in Climate Change 2001: The Scientific Basis, edited by: Houghton, J. T., Ding, Y., Griggs, D. J., et al., Cambridge University Press, Cambridge, UK, pp. 239-287, 2001.

Price, C. and Rind, D.: A simple lightning parameterization for calculating global lightning distributions, J. Geophys. Res., 97, 9919-9933, 1992.

Price, C., Penner, J., and Prather, M. J.: $\mathrm{NO}_{\mathrm{x}}$ from lightning: 1. Global distribution based on lightning physics, J. Geophys. Res., 102, 5929-5941, 1997.

Roelofs, G.-J. and Lelieveld, J.: Distribution and budget of $\mathrm{O}_{3}$ in the troposphere calculated with a chemistry general circulation model, J. Geophys. Res., 100(D10), 20 983-20 998, 1995.

Roelofs, G.-J. and Lelieveld, J.: Model study of cross-tropopause $\mathrm{O}_{3}$ transports on tropospheric $\mathrm{O}_{3}$ levels, Tellus, 49B, 38-55, 1997.

Roelofs, G.-J. and Lelieveld, J.: Tropospheric ozone simulation with a chemistry-general circulation model: Influence of higher hydrocarbon chemistry, J. Geophys. Res., 105(D18), 22697 $22712,2000$.

Rotman, D. A., Atherton, C. S., Bergmann, D. J., et al.: IMPACT, the LLNL 3-D global atmospheric chemical transport model for the combined troposphere and stratosphere: Model description and analysis of ozone and other trace gases, J. Geophys. Res., 109, D04303, doi:10.1029/2002JD003155, 2004.

Shindell, D. T., Grenfell, J. L., Rind, D., and Grewe, V.: Chemistryclimate interactions in the Goddard Institute for Space Studies general circulation model. 1 . Tropospheric chemistry model description and evaluation, J. Geophys. Res., 106(D8), 8047-8075, 2001.

Shindell, D. T., Faluvegi, G., and Bell, N.: Preindustrial to present day radiative forcing by tropospheric ozone from improved simulations with the GISS chemistry-climate GCM, Atmos. Chem. Phys., 3, 1675-1702, 2003,

http://www.atmos-chem-phys.net/3/1675/2003/. 
Shindell, D. T., Faluvegi, G., Stevenson, D. S., et al.: Multimodel simulations of carbon monoxide: Comparison with observations and projected near-future changes, J. Geophys. Res., 111, D19306, doi:10.1029/2006JD007100, 2006.

Stevenson, D. S., Johnson, C. E., Collins, W. J., Derwent, R. G., and Edwards, J. M.: Future tropospheric ozone radiative forcing and methane turnover - the impact of climate change, Geophys. Res. Lett., 27, 2073-2076, 2000.

Stevenson, D. S., Doherty, R. M., Sanderson, M. G., Collins, W. J., Johnson, C. E., and Derwent, R. G.: Radiative forcing from aircraft $\mathrm{NO}_{\mathrm{x}}$ emissions: Mechanisms and seasonal dependence, J. Geophys. Res., 109, D17307, doi:10.1029/2004JD004759, 2004.

Stevenson, D., Dentener, F. J., Schultz, M. G., et al.: Multi-model ensemble simulations of present-day and nearfuture tropospheric ozone, J. Geophys. Res., 111, D08301, doi:10.1029/2005JD006338, 2006.

Sudo, K. and Takahashi, M.: Simulation of tropospheric ozone changes during 1997-1998 El Niño: Meteorological impact on tropospheric photochemistry, Geophys. Res. Lett., 28, 40914094, 2001.

Sudo, K., Takahashi, M., and Akimoto, H.: CHASER: A global chemical model of the troposphere 2. Model results and evaluation, J. Geophys. Res., 107, 4586, doi:10.1029/2001JD001114, 2002.

Tie, X., Madronich, S., Walters, S., Zhang, R., Rasch, P., and Collins, W.: Effect of clouds on photolysis and oxidants in the troposphere, J. Geophys. Res., 108(D20), 4642, doi:10.1029/2003JD003659, 2003.

Thompson, A. M., Witte, J. C., McPeters, R. D., et al.: Southern Hemisphere Additional Ozonesondes (SHADOZ) 1998-2000 tropical ozone climatology 1. Comparison with Total Ozone Mapping Spectrometer (TOMS) and groundbased measurements, J. Geophys. Res., 108(D2), 8238, doi:10.1029/2001JD000967, 2003.

van der Werf, G. R., Randerson, T. J., Collatz, J., and Giglio, L.: Carbon emissions from fires in tropical and subtropical ecosystems, Global Change Biol., 9, 547-562, 2003.

van Noije, T. P. C., Eskes, H. J., van Weele, M., and van Velthoven, P. F. J.: Implications of the enhanced Brewer-Dobson circulation in European Centre for Medium-Range Weather Forecasts reanalysis ERA-40 for the stratosphere- troposphere exchange of ozone in global chemistry transport models, J. Geophys. Res., 109, D19308, doi:10.1029/2004JD004586, 2004.

van Noije, T. P. C., Segers, A. J., and van Velthoven, P. F. J.: Time series of the stratosphere-troposphere exchange of ozone simulated with reanalyzed and operational forecast data, J. Geophys. Res., 111, D03301, doi:10.1029/2005JD006081, 2006. von Kuhlmann, R., Lawrence, M. G., Crutzen, P. J., and Rasch, P. J.: A model for studies of tropospheric ozone and nonmethane hydrocarbons: Model description and ozone results, J. Geophys. Res., 108(D9), 4294, doi:10.1029/2002JD002893, 2003.

von Kuhlmann, R., Lawrence, M. G., Pöschl, U., and Crutzen, P. J.: Sensitivities in global scale modeling of isoprene, Atmos. Chem. Phys., 4, 1-17, 2004, http://www.atmos-chem-phys.net/4/1/2004/.

Wang, Y., Logan, J. A., and Jacob, D. J.: Global simulation of tropospheric $\mathrm{O}_{3}-\mathrm{NO}_{\mathrm{x}}$-hydrocarbon chemistry. 2. Model evaluation and global ozone budget, J. Geophys. Res., 103, 10 727-10 755, 1998.

Wauben, W. M. F., Fortuin, J. P. F., van Velthoven, P. F. J., and Kelder, H.: Comparison of modelled ozone distributions with sonde and satellite observations, J. Geophys. Res., 103, 35113530, 1998.

Wesely, M. L.: Parameterization of surface resistances to gaseous dry deposition in regional-scale numerical models, Atmos. Environ., 23, 1293-1304. 1989.

Wild, O. and Prather, M. J.: Excitation of the primary tropospheric chemical mode in a global 3-D model, J. Geophys. Res., 105, 24 647-24 660, 2000.

Wild, O. and Prather, M. J.: Global tropospheric ozone modelling: Quantifying errors due to grid resolution, J. Geophys. Res., 111, D11305, doi:10.1029/2005JD006605, 2006.

Wild, O., Zhu, X., and Prather, M. J.: Fast-J: Accurate simulation of in- and below-cloud photolysis in tropospheric chemical models, J. Atmos. Chem., 37, 245-282, 2000.

Wild, O., Pochanart, P., and Akimoto, H.: Trans-Eurasian transport of ozone and its precursors, J. Geophys. Res., 109, D11302, doi:10.1029/2003JD004501, 2004.

Wong, S., Wang, W.-C., Isaksen, I. S. A., Berntsen, T. K., and Sundet, J. K.: A global climate-chemistry model study of presentday tropospheric chemistry and radiative forcing from changes in tropospheric $\mathrm{O}_{3}$ since the preindustrial period, J. Geophys. Res., 109, D11309, doi:10.1029/2003JD003998, 2004.

Wu, S., Mickley, L. J., Jacob, D. J., Logan, J. A., Yantosca, R. M., and Rind, D.: Why are there large differences between models in global budgets of tropospheric ozone?, J. Geophys. Res., 112, D05302, doi:10.1029/2006JD007801, 2007.

Zeng, G. and Pyle, J. A.: Influence of El Niño Southern Oscillation on stratosphere/troposphere exchange and the global tropospheric ozone budget, Geophys. Res. Lett., 32, L01814, doi:10.1029/2004GL021353, 2005. 